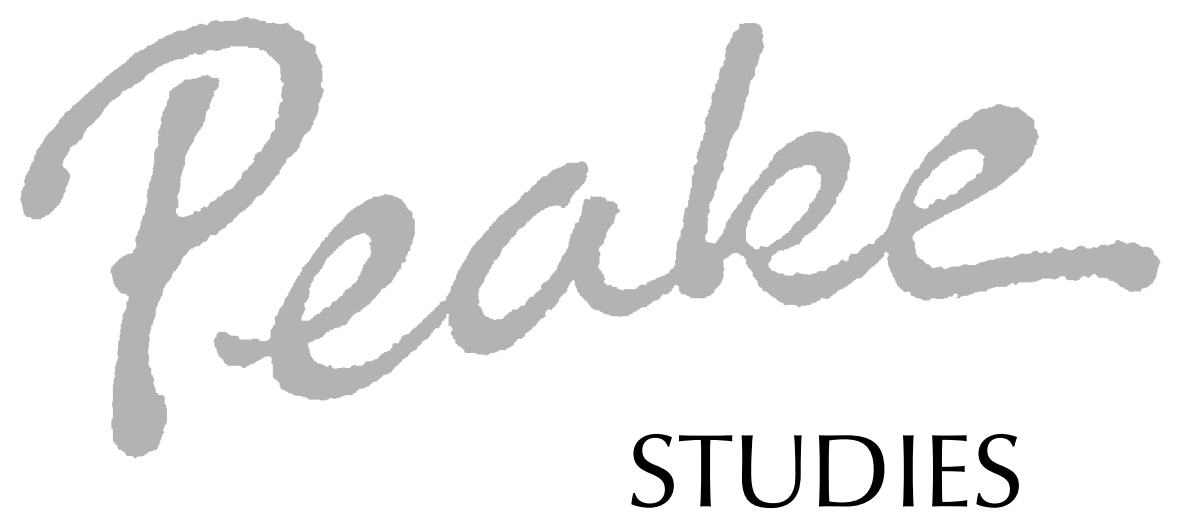

Vol. 14, no 1

October 2014

Unless otherwise indicated, the contents of Peake stUdies are (C) G. Peter Winnington 2014.

Acknowledgement is made to the Mervyn Peake Estate for permission to reproduce Mervyn Peake's words and images. The previously unpublished work by Mervyn Peake in this issue is (C) the Mervyn Peake Estate 2014.

Edited and published by

G. Peter Winnington, 2 ch. du Collège,

I 453 Mauborget, Switzerland.

Tel. +4I 244362232

E-mail peakestudies@gmail.com

Home page http://peakestudies.com 


\title{
Mr Loftus
}

or

And a Horse of Air

\author{
by
}

Mervyn Peake

in 2 acts of 4 scenes 


\section{Introduction}

MR LOFTUS is the last of Peake's unpublished plays, in manuscript and typescript, that Sebastian Peake sent to me for publication in Peake Studies. I have not reproduced it until now for the simple reason that it is much longer than the printed format of the journal could accommodate. Digital publishing knowing no such constraints, here it is.

Of all Peake's unpublished plays, Mr Loftus is the most complete, and comes in a variety of forms. The Peake archive in the British Library contains:

I. A notebook (Add MS 8893I/3/3/I) containing a draft of Act I, Scenes I-2. Some of the pencil annotations appear to be in Aaron Judah's hand. (There are also four pages of crossed-out text, titled 'My Home, My Wilderness: a play to show conflict between instinctive belief and inner reality - and rationalism'. These words seem to suggest something of what Peake was aiming at in Mr Loftus. This text has not been published yet.)

2. Another notebook, titled 'Loftus: The Catalyst' containing a draft of Act III Scene I, plus another 28 loose leaves of manuscript (Add MS 8893 I/3/3/2). As above, both contain pages in Aaron Judah's hand.

3. A typescript titled 'And a Horse of Air' (BL Add MS 8893 I/ $3 / 3 / 3)$.

4. A further typescript originally titled 'Mr Loftus or a Horse of Air' which Maeve Gilmore amended by hand to 'Mr Loftus by Mervyn Peake in conjunction with Aaron Judah' (Add MS 8893 I/3/3/4).

The BL catalogue attributes all the above to the 1950 .

5. A later version of Act I Scene I, typescript Add MS 8893 I/ 3/3/5, which is undated but which the BL attributes to the I 96 os or 70 .

6. A typescript titled 'Mr Loftus', which the BL attributes to the I970s (Add MS 88931/3/3/6), describing it as a 'copy of [an] earlier version of the script (as at Add MS 88931/3/3/3), seemingly produced on an electronic typewriter. First leaf inscribed in red ink in 
Maeve Gilmore's hand: “This play was written between circa I954-55, and was based on a theme suggested to Mervyn by Aaron Judah."”

Intriguingly, the typescript that Sebastian photocopied for me corresponds to none of the above. The title page reads 'Mr Loftus / or / And a Horse of Air / in 2 acts of 4 scenes,' followed by the list of acts and scenes (as reproduced on page 8 ). There are no annotations by Maeve, and just a few pencilled corrections of typos. To distinguish it from the copies in the Peake archive at the BL, I shall call it version SP (since it was supplied by Sebastian Peake). The text of SP corresponds to the BL's item 4, except that it does not generally respect the light pencilled amendments in Peake's hand present in item 4 .

So the question arises: is SP to be preferred to the versions of $\mathrm{Mr}$ Loftus in the BL? I have carefully examined the amendments in item 4. A few, found only in the opening pages, are just verbal improvements. (In the second paragraph of the opening stage directions, 'it is manifest' is changed to 'it is obvious' and 'a recumbent form' becomes 'a slouching form'.) Then there are a good many proposed omissions. For instance, the first two lines of the play, spoken by the Porter, are crossed out. Some of these omissions make good sense; in fact, the longest of them, two typescript pages in length, opening Act II, scene I, is also omitted in SP; others, however, would leave incomplete sentences and awkward breaks. One passage is marked 'shorten' without indicating what exactly should be cut. So, by and large, these revisions show Peake thinking about his text, rather than taking firm decisions to revise.

Item 4 also proposes additions. None add anything substantial to the play. One of them gives Mr Loftus a wooden hand - a memory, no doubt, of the commanding officer of Peake's camp on Salisbury Plain). Since this idea is not developed in any way, adding it at this point would be a mere distraction.

All these differences, including the correction of typos that are present in item 4, lead me to conclude that SP is a later version of the play. So I have chosen to print it as the best available. (The typewriter used was clearly an electric one, but that does not provide a date, 
since electric typewriters were used by professionals from the midI 960 s onwards.) I have not made any of the cuts proposed in item 4; any future production of the play will want to make its own cuts.

What about Aaron Judah's share in this play? Of the various passages in his handwriting that I have seen, none are retained in SP. Nor do any of the actions they describe feature in the play, either. So while there is every reason to accept Maeve's assertion that the play 'was based on a theme suggested to Mervyn by Aaron Judah,' I believe that it is very much Peake's own work. To start with, $\mathrm{Mr}$ Loftus takes up themes that are familiar to us from the Titus books. In his need for solitude, for instance, Loftus himself shares some of the characteristics of both Sepulchrave and Rottcodd. To Loftus himself are attributed passages from Peake's own writings, which suggests a decree of identification with his character. (Notes on these passages will be found on page 105.) Like The Wit to Woo, this play opens with sound rather than dialogue - in The Voice of the Heart, I demonstrated the importance of sound for Peake in his writing, whether prose or verse; in his fiction, his most memorable characters are heard before they are seen. In other words, in theme and technique, $\mathrm{Mr}$ Loftus is typical of Peake. I do not think that Malcolm Yorke was correct in asserting that Aaron Judah and Peake 'collaborated on Mr Loftus' (p.264). In my view, this text, at any rate, is entirely Mervyn Peake's.

In one respect $\mathrm{Mr}$ Loftus is not typical of Peake, which might suggest the influence of another person: he was not in the habit of making classical allusions or quoting Latin tags in his writing. This play mentions the Roman lyric poet Horace (and makes schoolboy jokes about his name), attributing to him lines that are in fact by Shelley. It also has a sub-title that quotes from Tom o'Bedlam's celebrated song. The notes for a story about Queen Zenobia and King Odaenathus of Palmyra at the end of item 2 in the Peake archive are equally uncharacteristic, again suggesting some outside influence, which may possibly have been Aaron Judah. (I confess to knowing nothing about Judah, apart from what John Watney wrote in Mervyn Peake and Malcolm Yorke repeated: that he was a theatre dresser who rented a room in the Peakes' Wallington house. He wrote a few 
works for children, including A Pot of Gold (1959) which Peake illustrated, but no plays.)

Peake made various attempts to have $\mathrm{Mr}$ Loftus performed. In his biography, Malcolm Yorke quotes from two responses, starting with Laurence Oliver, who 'wrote back with more than usual directness:'

I must honestly tell you that in my opinion I do not believe it quite makes the necessary grade. Original and extremely good as is most of the writing, I rather fear that the 'crazy' (horrid word but I can think of no other) theme is a highly dangerous one and the audience is apt to get irritated by it. ...

Also the rhythm in your writing together with a sort of verbal and onomatopoeic (spelling?) joking is trickily reminiscent of Fry and I do fear the sensation of it being derivative from both this author and Wilde and falling rather short of matching the content of either.

Kenneth Tynan voiced much the same fears:

I can see in it some fine pointed writing, and a lot of unforced pathos, plus a lovely part for a bravura actor to sink his teeth into. What slightly worries me is what might be called a foothold in reality. Your characters weave some splendid verbal wreaths for themselves, but seem to be figures in a pageant rather than people in a play.

Not surprisingly, Peake never managed to get Mr Loftus staged.

GPW

\section{References}

Watney, John. Mervyn Peake. * Michael Joseph, I976.

Winnington, G. Peter. The Voice of the Heart: the Working of Mervyn Peake's Imagination. Liverpool UP, 2006.

Yorke, Malcolm. Mervyn Peake. My Eyes Mint Gold: a life. John Murray, 2000.

* Watney mis-read Peake's MS and in his book gave the sub-title of this play as 'A House of Air.' 
Act I: Scene I

Act I: Scene 2

Act II: Scene I

Act II: Scene 2
Time: the Present

One Hour Later

INTERVAL

One Week Later

One month Later 
DRAMATIS PERSONAE

in order of appearance

$\begin{array}{ll}\text { PILCHER } & \text { Loftus's servant } \\ \text { PORTER } & \\ \text { GEORGE LOFTUS } & \\ \text { POSGATE } & \text { a friend of Loftus's } \\ \text { JANE NICHOLSON } & \text { daughter of Loftus's landlord } \\ \text { REV. TICKFORD } & \\ \text { PRINGLE } & \text { a friend of Loftus's } \\ \text { MARTIN CRESSEY } & \text { a friend of Loftus's } \\ \text { NEVILLE } & \text { Loftus's young nephew } \\ \text { MRS ANTHEA VOLE } & \\ \text { FLORA } & \\ \text { VICTOR GREEN } & \\ \text { FIREMAN } & \end{array}$





\section{Act I \\ Scene 1}

Early October, an hour before sundown.

The curtain rises on darkness. Nothing can be distinguished, but certain sounds are perceptible: the monotonous patter of heavy rain on the roof-tiles argues that this room is situated at the top of a building; the faint rumble of receding thunder and the drip-drip of water into a bucket.

Gradually the rain abates and the stage gets lighter. The rectangular curtained areas of the window upstage are seen to glow brightly and it is manifest that the clouds have rolled away from the sinking sun. It is still difficult to see more than vague indeterminate shapes, one of which suggests a low couch occupied by a recumbent form. This object is slightly upstage centre, and is inclined so that its occupant faces away from the main doorway in the right-hand wall.

The dripping of the leak from the roof has slowed down and a moment before the entrance of Pilcher, Loftus's servant, and the Porter, the last heavy drop has fallen.

Porter No, Mr Pilcher, no!

Oh ain't it murky!

Pilcher Please mind your feet

My friend.

PORTER Pardon, I'm sure. But listen:

I tell you straight, this is the boss's last

And final notice. He's an angry man

Is the landlord!

PIlcher Angry? That's rich! 
Why, friend, it's me what ought to be fair steaming!

Has Mr Nicholson had such a thing

As that dark hummock on his plate for nigh

On fifteen years? (Points to the heap on the couch)

I tell you it has damn' near screwed me!

Give me your notice of eviction, friend,

I'll see to it. ...

What are you waiting for?

PORTER (trying to make a stand) No, not this time! I'll speak to him myself.

Landlord's orders.

He shuffles rapidly to the closed curtains with the intention of flinging them apart. But Pilcher intercepts him.

Pilcher Have you gone mad? D'you want wake him, eh?

You disappoint me, friend. You might have guessed.

Porter Guessed what?

Pilcher That he is ill,

Porter Ill? Why, what's the-?

PIlcher No, no - don't interrupt, his kind of sickness

Is not the sort of thing you'll find in books.

He is a law to himself.

Porter Is he now? And what's so special-?

Pilcher Oh ignorance! Ain't there not grades of men

Like there are grades of animals?

PORTER Well?

Pilcher Well, don't, you see? You can't go fooling round

A man like this with your eviction papers -

No more than you can ask a flipping race-horse

To lug a milk van. No, he aren't like us,

To be disturbed. Oh, there's some depth, there is,

In this black hump.

PORTER Well? Does that make him ill?

Pilcher Of course, it does! How could you have a hundred

Horse power brain and still keep healthy, friend?

It's like a bloody pumpkin on the shoulders, I shouldn't wonder. 
Loftus turns over in his sleep and mutters.

Pilcher Did you hear that? I advise you to be off.

We'll meet again, no doubt.

He puts an arm across the Porter's shoulders, but the Porter shakes him off.

PORTER I must talk to him.

Pilcher What can you say to him whose soul and body

Eat one another up?

Are you blind to suffering?

To scholarship? To genius itself 'n' all?

Porter But what can I do, Mister? Have a heart!

As for myself the gentleman could stay

Here all his life. But who am I?

(He peers through a chink in the curtains.)

It's wasted on him though, this studio flat -

Roof garden 'n' all, and such a view of London.

Why there's been foreign gents as rich as pork

Who've offered bloody thousands for this crow's nest.

And the way you keep it! Strike a light!

A log of wood could smell it three floors down!

Pilcher Are you saying as I'm filthy, friend?

D'you know how many times a day I put

A broom to the floor - only to have him yell

At me to leave the studio alone?

Some days he shouts that it's sacred soil.

On other days he says it makes him choke.

What can I do? Now give me your advice,

You are a porter, ain't you, after all?

Porter I am, and what I say is-

Pilcher Agreed.

There's something quite out of the usual run

Of men asleep beneath that humble blanket.

Porter I didn't say nothing! What I said was how

The landlord wants this flat particular!

'N' I'll tell you for why,

It's to be his wedding present to his daughter. 
She and 'er Victor Green's going to live here Here and for always in the studio flat, Just like it used to be before the cobwebs All pink and creamy with thick fitted carpets, And slippery magazines, and big glass ashtrays.

Pilcher So you're impressed with landlords and their daughters?

$\mathrm{Ha}$, ha, ha! What d'you think all this Will mean to Mr Loftus when he wakes?

He lives in quite another world apart, You don't know anything of him Why, by the time he was thirty, friend, He was a doctor, lawyer, 'n' a linguist Greek, Persian, and all the rest. He's written books What no one understands - thesesses 'n' all On tombs in Syria - and what is more, He's got an epic up his sleeve, he has.

PORTER What's that?

Pilcher A Masterpiece. 'E's made some notes already, In a Green Copy-book. You haven't got it: He's not the kind of man you can evict. And what is more - this is the heart of it The landlord's daughter, Jane, who wants this flat, By your accounts, is sweet on him herself But never breathe it!

Porter Well, sew me up! Miss Nicholson and 'im! Pilcher Not that she gets much change out of the governor. PORTER Well, sew-

PILCHER (offering him a selection of cigars) Do me a favour, friend, take a cigar.

The Porter takes one.

I thought you'd make a clever choice, old man!

Put a few in your pocket.

PORTER But are they yours?

Pilcher My motto is 'Honesty, honesty, And again, if necessary, honesty.'

Can it go wrong? 
Porter Well, well, fancy that! Miss Nicholson and 'im!

... Now then, this flat-

Pilcher (coaxing the Porter to the door) Exactly. He needs it,

Would you stifle the flame in the brain

Of this gentleman?

A sick man with his head among the stars?

(Stopping him)

Do you wish him clubbed to death with ignorance?

(Taking him on)

Of course you don't! You must be going?

Come again one day - not too soon.

Take this notice with you. I know you are grateful,

But think no more of it ... That's it, that's it ...

Through the door and to our right ...

And there we are indeed...

Exit Porter. The instant he has gone Pilcher rushes to the couch and starts shaking Loftus.

Pilcher Wake up, darnation, hell and creeping horse flies!

Oh curse the everlasting sloth of it!

How I could strike him! It's as bad as trying

To drag an anchor from the seabed slime!

Mr Loftus, sir! Mr Loftus!

Loftus (asleep) No! No! Unhook your talons! Let me fly!

Zenobia was always half seas over

And every desert dry as cork until

I lost my virtue!

PIlcher Mr Loftus! Oh curse you, sir!

It's six o'clock!

Loftus (asleep) Let me alone, you rat!

Get off my ship! Green gangplanks! Curse the sea

For being water. Hell, what shakes us?

There isn't any wind. Stop shaking!

Who is it, damn you?

(He wakes.)

Since when have you acquired the privilege

Of rocking me awake? Keep further off: 
You smell of activity.

Pilcher He's been here again. He brought black tidings.

Loftus White tidings could be worse - bad for the eyes and soul But black - soft, thick, warm and impenetrable, Black is my favourite colour.

'Tidings', you say? Who from?

Who brought them? But, first of all, tea:

The aromatic leaf.

'Tidings'? What a word to use. Has a doctor Been here? What? What? Am I dying?

Pilcher Far worse than that... The porter's been.

Loftus How fascinating. The porter ...

How I wish $I$ could call myself something.

Or that I were something.

A blacksmith, a pearl-diver, a rat catcher,

A bus conductor, or a thief.

They know what they are, these fellows;

They can write it down in a word.

What am I?

Pilcher You're you, Mr Loftus.

Loftus Am I? How morbid for me. Never mind. . . .

What did he want?

Pilcher He came to say the landlord is now issuing

The final order for your eviction.

She's to be married in a day or two,

And plans to live here

This flat's the old man's present to her

In perpetuity.

Loftus Have you woken me up to tell me this?

Pilcher No, no - for we will never leave here, sir.

Will we, sir? Oh no, there was another matter.

Today the fourth, sir, is the Bradcock party.

Loftus To hell with the Bradcock and her parties.

Why does she go on badgering me?

It would mean getting up. Where is it? 
Pilcher Only the flat below, as usual.

Loftus Too near.... and too far.

I'd rather be where I am

And count my toes. Leave me, I'm tired.

I must brood a little.

Pilcher Brood? Do you know it's half past six!

Loftus mumbles something protestingly.

Morning? Morning? It's evening!

I'll show you!

Pilcher runs grotesquely to the closed curtains and, deaf to Loftus's frantic cries of 'No! No!' tears them aside. The most brilliant beams of sunset pour into the room and blind Loftus ...

In the transfiguring light fresh objects can be seen: a cuckoo clock, the broken cuckoo lolling out; the bucket that has been collecting drops and which is standing in an ornate basin, which in its turn stands on a Japanese table.

Loftus (shielding his eyes) What is it?

PILCHer Eh?

Loftus Take it away!

PIlcher What?

Loftus That yellow light. Switch off the stuff at once!

What right have you to let the brightness in

All of burst? What is it? If you say

It is the sun, I'll sack you.

The sun was made for pharaohs, and for beggars

That kneel crutch-deep in dust as warm and soft

As sweet decay. No, no, it's not for me.

Cut its gold throat.

Pilcher (leaving) Yes sir, of course.

Loftus Come back! I'm getting used to it.

Pilcher Yes, sir.

Loftus Why don't you wake me earlier than this?

You have no method.

You know I can't afford to sleep for more

Than two hours after lunch. I have my work!

Eh? 
Pilcher I tried. One has to dig for you, sir.

Awaking you is like some dreadful deed

In a bone yard. I have never liked it, But I do it for you - I look after you -

I let you sleep. It is only when there is

A special party in your honour...

Loftus You want me like this - that's what it is!

I can see through you. The longer I'm asleep

The less work for you, isn't that it?

(A sullen silence)

Look at that picture - all askew - it's been

Like that for months - yet you do nothing.

You're a leech in my side...

Look at it!

Pilcher You've never complained before...

Why start now?

Loftus Why 'Now'? 'Now' is the time for starting!

'Now' is the only time!

Wake up and grip it!

(Pointing to cuckoo)

Look at that unholy

Bird, like something retching over Biscay.

It makes ms sick to see it. Push it back,

Why do you pull it out?

Pilcher I never pull it out. It comes out, sir.

What is the good of putting it back?

It always comes out again. Always.

As he says this Pilcher reluctantly climbs upon a chair and pushes the cuckoo back into the clock. To his surprise it remains there.

Loftus And the cobwebs! Look at them!

Cartloads of gossamer. Have you no pride?

PILcher You told me how you liked the look of it.

Hanging like robes, you said, and how

You could spend hours making pictures up

Out of the filthy stuff.

Battles and mermaids and the rest of it. 
And now you blame me! Me!

Loftus What's that bucket doing on my Japanese table?

PILCher It's been there since Thursday!

Loftus I said, what's it doing there?

PILCher The ceiling leaks.

Loftus What's the basin for?

Pilcher The bucket leaks.

Loftus Everything leaks. The world leaks. My heart

Leaks. 'The blood runs all away.'

As for you - you're a kind of lesser leak -

A dirty little dribble - drip, drip, drip -

Wearing me away, although in my youth

I was granite.

But I am not entirely rendered down,

I have my own kind of vitality:

The valet has heard all this this before. With a 'there-he-goes-again' sort of expression, he leans against the side of a chair.

Between these blankets, Pilcher,

I have, in darkness, seen the ice-green light

Of zoneless poems. I have taken

The square root of the globe;

I have more sunlight in my head, dear crab,

Than you have ever felt upon your face...

That's good! (Searching around)

Where is my epic? Have you seen it?

Look for it! Yes, very good. That must go in.

Where is it, my green copy book?

Pilcher Oh that? What d'you want that for?

Loftus Where is it?

Pilcher How should I know? I thought you'd given it up.

Loftus 'Given it up'?

Pilcher You haven't done nothing to it for donkey's years.

Loftus Haven't I? What's that to you?

(Filling with rage) To it! To it!

Pilcher To what?

LofTus To work, you son of sloth! 
Pilcher Sloth! For you to. ...!

LofTus To work, or it's the sack! The manuscript!

No, no, not there! . . . First thing's first - when you've swept

And dusted the whole damn' studio

I'll have my tea and brandy.

... Stir them! Stir them!

Those dreadful legs of yours - these obsequious legs!

Stir them and clean the room out!

Pilcher You've never! Never-! Why we 'aven't even

A vacuum cleaner!

Loftus You heard me!

Pilcher Now?

Loftus Now in the pulp of it!

In the silence that follows Pilcher ominously begins to roll up his sleeves as though about to accept a challenge for fisticuffs. Loftus has begun to read a book. Pilcher gets mop, bucket, etc.... He bends and starts rolling up the carpet as far as he can, i.e. to the point where it is stopped by the couch legs and where the two men come face to face.

Pilcher The dust is ankle deep...

That, sir, is surely not as you would wish it.

I must be thorough, mustn't I?

Loftus Do you mean I must - ?

Pilcher Naturally, otherwise how can I-?

Loftus Perhaps if you began with - ?

Pilcher Come off it, sir! The spadework first, And then the feather duster. ...

To your feet, Mr Loftus.

Loftus But this is-

Damn it all, isn't the morning the best time -

Or perhaps in the winter it would be better Something to keep you warm-

Pilcher Very well, if you prefer to have

The room left as it is -

Loftus You're mocking me! You must have known 
That I was speaking figuratively,

Yet you choose to tease a sick man.

Are you looking for dismissal?

(He sinks back, exhausted.)

I was just going to get up -

Now you've upset me.

The cuckoo shoots out and delivers its idiotic phrase. It remains out, hanging brokenly. Pilcher, hardly able to conceal his triumph, rolls back the carpet.

PILCher Would tea be welcome, sir?

Loftus Yes, yes, dear fellow, make the tea You do that.

Pilcher We do understand each other, do we not, sir?

That is something to be grateful for

In this hard world -

And rest assured, sir, if I run across

The manuscript-

Loftus Oh, get the tea!

Exit Pilcher.

Loftus lies motionless for a few seconds, and then fumbles under the cushions. Eventually he finds a little flute. He is interrupted by the ringing of the telephone.

Loftus Pilcher! (no answer) Pilcher!

Loftus cannot quite reach the phone which is on a covered table nearby. He starts dragging at the tablecloth to get the instrument nearer. It slips onto the floor - still out of reach. A Voice starts croaking insistently, 'Hello? Hello?' Loftus does not attempt to reach it but answers from a distance.

Loftus (shouting) Hello! Who is it? ... What? . . Don't whisper?

Great hell, I've lost half my voice already! . . . Mrs Bradcock? . . . Your party . . . I'm not whispering! Today! ... In my honour?. . . Well ... .

Half way through this conversation Posgate's vulgar voice can be heard shouting through the front door:

Posgate Rag'n bones! Lovely lavender!

Filthy postcards! 
He enters without being invited and seeing Loftus phoning he goes to a mirror and combs his hair (with Loftus's comb) with a hideous concentration, whistling between his teeth and trying out a few antics to distract Loftus.

Loftus (to phone) What? . . But I don't want to meet him ... I don't care if he admires my books or not. . . . To please you? . . . Oh Lord, I don't like parties ... I don't like them! . . . Oh Lord, all right . . . yes, I promise . . . yes . . . yes, yes, I will, I will, now let me go! ... Ahhhh ... (He sinks back)

Posgate What a way to greet your old friend!

You bedsore!

He picks up a box of Loftus's cigars, pinches several of them and eventually lights one.

LofTus What gentle breeding.

Posgate picks up a book from those at the foot of the couch, glances at a page and flings it down.

Loftus Erudite as ever,

Posgate spits out of the window.

Hygienic as ever.

Posgate pours himself a drink.

Abstemious as ever

Posgate, pretending to be a rear gunner, squirts soda water across the stage, making a chattering noise with his mouth. Then he sits down and belches.

And as spiritual as ever. Oh Posgate,

You do not merely bring me down to earth -

You bury me.

Posgate Bury you? Ha, ha, ha!

You'd never notice it. You're a horizontal type.

Born horizontal, lives horizontal,

Dies horizontal, is buried horizontal,

Goes to hell horizontal. Here he lies:

The man who never grew up.

Good, eh? ... You great sack! What is it!

Who could guess by the way you stare at me

That I'm the chap who visits you each day 
To keep you lively?

Enter Pilcher with tray.

To stop you from brooding,

And reading all this philosophic nonsense.

Hell on earth, I give my time to you,

And Time is Money.

He takes a sandwich and continues to Pilcher.

How are you, Heart-throb?

By God, you're the scruffiest satellite

That ever circled round a human body!

What's this, tea? What are these, tomato?

Get your master a cup before I crown you.

Posgate has now drunk the tea and is half way through the sandwiches.

Pilcher (speechless) You - you -!

The door bell rings. Posgate turns unpleasantly to Pilcher.

Posgate: Answer it!

Pilcher I take no orders but from Mr Loftus, Answer it yourself.

Posgate Intolerable worm. Did you hear him, Georgie? (No answer) Georgie!

Loftus What's the matter? Your dreadful voice deflowers me.

Pilcher I opened it yesterday, sir.

Posgate It was me!

Loftus (singing) 'Twas only yesterday, my dear, As I remember well ...

The hinges worked on bottled beer

(Ring)

There goes the bloody bell.

Posgate Oh shut up, George.

Loftus And so I opened the door myself It was a long journey.

(Ring)

(to Pilcher) See who it is.

Pilcher Might be something urgent, sir.

Miss Nicholson, perhaps. 
Loftus No, no!

Pilcher retires.

Posgate goes to the door himself and the muttering of voices, partly a woman's, is heard without. Re-enter Posgate alone. He deposits a chair by Loftus's couch and makes other and more elaborate preparations for the visitor's entrance. He pays no attention to Loftus's enquiries.

What are you doing?...

Who is it?...

Posgate What is it, Georgie,

About you that attracts these humming birds,

These sprigs of Paradise?

Why, man, the very mention of your name

Upsets the ticking of their pretty hearts.

Ah, she's a gem.

Loftus Who is it? ...

Who are you talking about?

Posgate Jane.

Loftus Jane? What does she want?

Posgate What does she want? She wants you!

She hungers for you -

Why don't you let her eat you?

If I were you I'd marry her at once

And put her out of pain.

As for your own financial agony,

Well, holy hair cream! boy, you'd be on velvet.

Her father's rich as Croesus - and this flat

Will be your own - you'd never be disturbed.

It's my advice for what it's worth, old man,

To snap her up-

Loftus I'd rather be a flyblown pauper,

Alone, with myself.

Posgate Are you mad, Georgie? I don't get you,

Don't you see-?

Loftus Oh scuttle back to your corner, Posgate, I'm sick of the subject. What is it to you 
Whether I go or stay? Save if I go

I'll prove less of a rendez-vous for jackals.

No more about her. I'm tired of it all.

I will not see her.

Posgate A pity, because she insists on seeing you.

(Ring)

There she is!

As Posgate goes to the door, Loftus pulls the rug over his head. Posgate enters with Jane.

JANE Why have you kept me waiting?

Posgate Sssh - do you wish to speak to that?

The Earl of Mattress?

Sssh - you tread on sacred ground.

You are in the presence of

The cushioned Earl of Couchland. Ha, ha, ha!

You wish to speak to it: the deep sea monster?

Blow out, ye trumpets! Blare!

Sssh - isn't he pretty?

He makes to put his arm around Jane's waist.

JANE Take your hand away!

Posgate I say, what's up?

Jane Keep your distance ... (Pause)

You must wake him up. ... At once.

Posgate Why? He's probably afloat in a Greek dream.

JANE He'll have a rude awakening . . .

He must go.

Posgate But we've just been talking about you, dear!

Of nothing but you.

JANE How interesting

Posgate Georgie was saying what a long time It is since he last saw you.

Jane He must go ...

Posgate: Where could he go? He would be lost.

This flat is his home, Miss Nicholson.

But, blimey, don't it need a woman's touch!

A movement under the rug. 
I must be going, dear. He'll waken up

At any moment now. ... I know his habits.

(Going)

Oh Lord, what couldn't I be doing now

If I were in his place.

He pretends to leave by opening and closing the front door with a bang. Re-entering, he hides behind a screen. ... Jane stands looking helplessly at the heap on the couch. Silence, as she regards the chaos in the room. At last the 'earthquake' starts, and out of the rugs, cushions and books Loftus's head emerges. A tense pause.

JANE You must go. My father insists and so do I.

Loftus Go ... aaaah...

JANE (harshly) Go away, for ever, I-

Loftus Dear hell, why, d'you have to startle me?

Standing so close and barking.

JANE 'Barking'? How cruel - oh how cruel! (breaking down)

Enter Pilcher, undiscovered, with tray.

Loftus (to Jane) No, no! I implore you!

PILCHER 'PASSION.'

Exit with tray

JANE Go! I say, go! I cannot keep it up!

Loftus (with sad affectation) Down comes the rain,

Down comes the snow,

Poor little bleeder

'As nowhere to go;

No mother to love 'im,

In 'er grave she lies low,

Out in the wide world

Is poor little Joe...

(In grand tragic style)

'Go' - what a word it is!

You make a little noise of only two letters

And the doors of Hell creak open, and a ghoul

Beckons me in. I see the carious throne

That waits for me in his remorseless mouth,

Where I must sit for fifty million years, 
Chained to his crownless canine, shivering.

JANE Are you afraid?

Loftus Of course I'm afraid. Terrified.

That is why I gave up thinking.

It is a luxury I can't afford!

Unless I risk it that the breasts of madness

Are worth the sucking...

Did you say 'go'?

What's that? Stay still ... don't touch that hank of hair!

He finds a piece of paper and a pencil under his couch and starts drawing.

JANE 'Hank'? Why choose that word?

A 'lock' is no more difficult to say ...

Do you really wish to draw me?

Loftus It isn't you . . .

It is the hair that falls across the cheekbone.

JANE I understand...

It is lovely in here.

Loftus Is it? What's lovely about it?

JanE It's different from all the other flats.

It's real.

Loftus It's real enough,

You can stub your toe as well in here as elsewhere.

JANE It is more difficult to stub out love.

Loftus (still drawing) What's that? You are too subtle for me.

What have you come for?

He screws up the drawing and throws it away. Posgate undiscovered makes an exasperated gesture.

JANE (recovering the paper and smoothing it out)

I have taken a great liberty, I suppose,

Coming ... to you ... like this.

Loftus 'Coming to me?' I'm not a priest!

There's a dreadful servility in your voice.

JANE (touched to the raw) 'Servility'!

I will show you whether I am servile!

Enter Pilcher with tray 
I hate you! I hate myself!

I hate everything!

So I'm getting married.

Pilcher 'REVELATION.'

Exit Pilcher with tray.

JANE Well? ... Well!

Loftus I congratulate the young man, whoever he is.

Who is he?

JANE (her anger spent) What does that matter? It depends on you.

Loftus On me? What does?

He tries to reach his cigarettes.

JANE On you, for at a word the world could change.

Can't you understand? It was too much for me ...

The eternal waiting, waiting, waiting ...

You do not seem to care about the world

- That is what I loved. That is what I feared.

I loved you for this that keeps you from me ...

You have no need for anybody's love.

What can I do?

Loftus You can reach those cigarettes.

JANE (steeling herself) This is father's wedding present to me.

We shall be living here, here, very soon -

Victor and I.

It is I who have got father to evict you

And throw you out into the common street.

I want to live here - here where you have lived.

Loftus This is horrible. Do you mean that you

Are marrying to spite me?

Jane Why not? You ... you ...

Posgate, undiscovered, is very excited and hopeful.

Loftus Come here; it is a drought of time ago

Since I last saw tears.

You mustn't cry.

JANE But you could have it all! Free and for ever!

I wouldn't interfere. I'd understand.

I'd leave you with your sleep, your books, your dreams, 
And there'd be no more fear, nor debts at all Only the debts I'd owe you for the joy

Of being near you. Can't you understand?

Loftus And what of Victor Green?

JANE Oh Victor Green be blowed!

Loftus Can I believe my ears? Great hell! The fickle

Falsity and froth of thwarted women!

You shock me....

Why, you're as bad as I am. Both together

We could appal the earth and undermine

The sanctuaries. You with your perfidy -

I, with a ton of garbage going bad

Under my ribs, and a bad smell in my brain.

With such prerequisites to the art of living

We could get anywhere - do anything.

Mothers would snatch their children from our path,

Or turn a ghastly colour

To watch us sidle by, our fingers sticky

From the grey pit ...

JANE You play with words.

You play with me. You play with everything

That bruises. Your unhappy humour hurts me.

I would rather that you struck me. Underneath

Your flippant game I know that you are wounded.

You are full of wounds.

Oh, if you let me, I would guard you, Georgie,

From the world, the beastly, predatory world.

You do not understand how it must feel

To be in love.

It is because of this sharp malady

That I encouraged Victor, whose sweet nature

So bores me I could scream! And so I do!

I scream in terrible silence

Far all you mean to me; for all the darkness

That blankets you; for all the cruelty

That barbs you. Oh, whatever does it matter 
If you are good or evil; it is love

That has fallen from the unpredictable sky

And crushed me.

LofTus (holding her off) Oh spare me!

Oh spare me the responsibility

Of knowing what you feel.

I do not want emotion - spare me that.

The world's revulsion and the world's revenge

I can cope with, but not love; I will not have it.

Only look at me:

My talents, sweet, are withering away

And nothing but the shell or shadow of

What was once like a city in my skull

Now haunts me. I'm content. There is a dreadful pleas-

ure

In self-denial when the thing denied

Is the wild breath of genius in the bud.

You see, I am beyond all hope, blaspheming

In the face of vision; like an a idiot slinging

Filth at the Muses.

$\mathrm{Ha}$ ! Ha! Ha! Ha!

Whirl away! Whirl away, world!

Oh what a trip through space your one-way ticket

Provides us with! What's all the rush about?

We'll never catch the world up, anyway,

For all that there's a Dervish in our bones.

As for Creation,

We are so cluttered up with miracles, Why add to them? I am content to lie And contemplate my toes, or turn to see A moon float past the sky-light.

Let me be.

My vision sits beside my solar plexus

And when it rears its coloured head I slap it

Flat with a fly-whisk.

This is my world, to make or mar, my world, 
A shrivelled cube of air, a thing contracted That I can govern from a stranded couch.

I will not stir myself; I will not change, I will not mend my ways. Leave me alone.

JANE Do you think I would try to alter you?

Oh no! no! no! I'd leave you as you are, And in my love, and in my ignorance

I would sustain you.

She falls on her knees beside him. The door bell rings, the telephone rings, the Valet comes in and dumps the tray, Posgate cries from the shadows, 'Rag 'n' bones! Violets! Any old violets.' Loftus pulls the rug over his head as the CURTAIN descends. 



\section{Act I \\ Scene 2}

One hour later. The same scene. The last rays of sunset light the far wall. An atmosphere of acute frustration. Loftus and Posgate have been joined by the Rev. Tickford, a guest of the party downstairs. Loftus is as he was on the couch. Posgate is lounging in an easy chair. Jane is outside on the roof garden, where her silhouette can be seen, patient and motionless throughout.

TICKFORD This is awful - awful!

You can't do this to your hostess. Have a heart.

Poor Mrs Bradcock is beside herself.

Posgate How boring for her.

TickFord It isn't funny, my dear friend It really isn't funny.

(To Loftus) The party is very largely in your honour.

Oh dash it all! I feel quite ill and angry.

Posgate (to Loftus) He feels quite ill and angry.

(To Tickford) Ah, my dear sir,

Would that I had'st thy power for understatement.

He make you ill and angry! Flaming flies!

I've had years of him.

Posgate helps himself to one of Loftus's cigars.

Loftus Angry ... why?

TickFord Why, I will tell you why, sir, though it is far From my affair.

Posgate Come, come - not as far as all that, surely Is not the world's affair thy pigeon also? 
TiCKFORD You dismay me, my friend.

(To Loftus) She is distraught, Mr Loftus.

You were to be the focus of her party

Round which we all revolved. A little galling

But there it was. That is the gist of it.

Will you dress and come down, sir?

It is all most embarrassing.

Posgate Yet oh, how spicy.

What's your secret, old boy,

That lying here, an indolent hunk of clay,

Yet you can set the ladies in a twitch

A floor below.

Are you asleep, old man?

TickFord Oh surely not! This is preposterous!

Loftus (his eyes shut) So you would lure me from my fragrant nest.

TiCKFORD If only I could.

Loftus Is it so villainous to slumber here,

On my own couch, disturbing nobody?

What could be more innocent?

Yet you have it in your mind to pluck me forth

Like a fish from the sea.

Tickford Oh rise above it, Mr Loftus, in every sense.

Loftus Like some old Triton from the crumpled billows?

Tickford This is no time to linger

Over a phrase. Good Lord, it worries me

To see the sunset pouring through windows

To waste themselves on these despondent walls.

(To Posgate) Can't you do anything about it?

Posgate 'Tis not for me to wrench him from his dreams.

Noise of the party downstairs.

What a row they're making. What about the women?

Are there any - how shall I say-

TickFord Don't trouble to say anything to me,

I am quite sickened.

There seems to be no simple decency - no love -

No beauty in this dreadful room. 
Why did she ever have to pick on me

To fetch you down?

Posgate Ah, 'love' and 'beauty' -

Do you think you'll find them in the flat below?

With Mrs Bradcock?

Love and beauty, my foot!

What's that they're shouting?

VOICES FROM BELOW Come on down - come on down!

Tickford And so I will. I can do nothing with your friend.

Posgate And what do you want to do with him?

Alter him?

TiCKFORD I would be proud if I could do so, sir,

With God's guidance. His treatment of his hostess

Is nothing to his insolent dismissal

Of God's unending bounty.

I did not know that sloth could suck a man

So deep into the sedge.

(To Loftus) Shall I say you have no message for your hostess?

Is that what you want me to do?

Loftus (to Posgate) Can you see a black book with a yellow spine?

It should be somewhere there, near my left foot.

No, that's not it.

Posgate (picking up book) What, 'Horace'? And who's he when he's at home?

Hasn't the man a surname? (Opens book) Oh, Latin.

You can have him.

Loftus And a cigarette. They're on the floor, there,

In that slipper.

He elbows himself into a sitting position.

'Arethusa arose

From her couch of snows

In the Acogeranian mountains.'

He lights his cigarette, then turns to Tickford.

What can I do for you?

Tickford O God, give me strength -

I can't stand much more of it. 
As he makes for the door, the bell rings and he lets in another guest from below - a Mr Pringle.

Pringle Ah, there you are! Good, good. What on earth has kept you? What? Don't go, my dear man - don't go. And where is - oh, there he is! My dear Loftus! Good, good - but what a fearful sight, old man! What a pickle, eh? Dash it all, the party, my dear Georgie - it's waiting for you. What are you laughing at?

LoFTus is laughing at a Latin joke in his book.

TickFord The man is ill. Spiritually ill.

Pringle Who, Georgie Loftus? Nonsense! Ill? What does that mean? Define it. We are all ill. Or, conversely, none of us are ill. Smoke, mere smoke. As for 'spiritually ill': fiddlesticks. It's all perfectly clear. Poor Georgie - dear Georgie - has always been at war with his own psyche. Haven't you, George?

Posgate Have you, George?

Tickford Be quiet. (To Pringle) You and your spurious theories. The man needs God. It's a simple as that.

Pringle 'God'! That silly word.

I get so tired of people putting up words

To hide themselves behind. Now listen -

Tickford Let go of my sleeve! What good to him are your Cold, half-digested theories?

The man needs warmth. The church could take him in.

LofTus fishes out a flute from somewhere and starts playing some old air.

Pringle It would be a squeeze.

He has too large a presence, what? What?

It would burst a cathedral, what?

No, no. Let's be rational.

Tickford Why?

PRINGLE What?

TICKFORD Is the earth rational? Is beauty

Rational? Is love rational?

Why tell me to be rational? There's nothing 
Rational will ever help this pitiful

Fellow.

Pringle and Tickford retire upstage still arguing.

Voices from below, 'Come on down!'

CRESSEY (from doorway) May I come in?

LofTus (stopping his flute playing and greeting in tones of almost enthusiasm) Martin!

Posgate Oh, it's you, Cressey, is it?

Why can't it be a woman for a change?

Too much of my damn' gender gets me down.

CRESSEy (to Loftus, ignoring Posgate's rude interruptions throughout)

O my dear chap, you disappoint me.

Posgate Big brother is so disappointed!

He has such a beautiful nature!

Cressey (to Loftus) For God's sake look alive!

And leave that toy alone. Sit up, old man,

And get some kind of grip.

Your hostess is upset that you have failed

To keep your promise. She wants you. Everyone

Wants you. Why? Nobody knows - but there it is.

Do you want to hurt Mrs Bradcock?

Posgate 'Here endeth the first lesson.'

How can you bear his lectures?

You're a bloody old woman, Cressey.

Why don't you go back to the festivities

And leave him alone?

Cressey (to Loftus) How can you suffer it?

Is it because the sight of him reminds you

Of how your thick, accumulated sloth

Is less atrocious than a passing whiff

From this jackal?

Loftus Well put.

Cressey I'm not trying to put anything

Well, or otherwise.

I'm too stirred for that.

Posgate I'd rather reek like an army of jackals 
Than wallow in your sanctimonious oil.

Loftus Very nice.

Cressey 'Very nice'! Damn and blast you, Georgie!

Voices from below Come - on - down!

Cressey Let us, indeed, go down.

Why the devil we came up I cannot think.

Posgate You can't change him.

He's too deep in himself,

Aren't you Georgie?

TicKFORD (returning from roof garden with Pringle where they have

been arguing) You are his friend.

Cressey I am.

TICKFORD Tell him to leave this room and go away.

Tell him to leave behind his friends, and go.

And in some foreign climate of the mind

He may, one evening, wandering alone,

Discover in the posture of a beggar,

Or in the shape of some tall, heaving tree,

The unimaginable love of God.

Oh, tell him he must go -

This place destroys him.

Loftus 'Ab imo pectore et ad intra initio.'

TickFord He's vaster than any of us.

We do our best within a little field;

He does nothing in a great wilderness.

Pringle Aha, you do see, don't you, gentlemen,

The outline of this thing?

This dreadful couch he lives on is his mother -

In other words a ship. You do see that?

What kind of ship? A pirate ship of course!

An anti-social ship.

This frightful carpet

Is the Southern Seas, these walls are coral islands,

Symbols of adolescence. He thinks we are his crew.

Don't interrupt me please! And, for the love of lilies,

Don't go - where were we? - yes, yes, I could cure him. 
Cressey Be quiet ...

I would no more leave you alone with Georgie

Than I would leave a turkey with a fox.

Pirate? What an ass you are.

His was a great brain. He has deserted it.

But it was a great brain.

TiCKFORD I felt it - I felt it from the first.

I have been angry through lack of vision.

All I saw was a sluggard.

But he is ill. He must be loved.

Posgate That's it! He needs a woman.

LofTus (coming to life) Well, well! I'm more than flattered, gentlemen,

That my unworthy room should make so snug

A venue. Ah, what a Hogarthian pattern

You have arranged across my jaded eye.

What excellent grouping. What a splendid tableau!

Yet this means nothing to you, does it, Posgate?

Posgate Why pick on me?

Loftus It is a monstrous conversation-piece

In which we all appear, though none of us

Includes himself within the picture-frame.

Each one of us is always left outside

On all occasions. Hence the horrors -

Shame, loneliness, aggression and the horrors.

And so .... the horrors.

Pringle 'Horrors!' Did you hear that? The Collective Unconscious;

Behemoth and the stag with bloody gums, what!

It's quite simple, what?

Tickford You darken me.

Loftus (to Cressey) How is your lady friend?

Why don't you keep her with you?

You could give her a glimpse of me -

From the door. Not too close, you understand -

For the smell of dry-rot is harmful 
To the lungs of delicate creatures.

What's her name? I keep forgetting.

Cressey Flora.

Loftus Ah yes, all sap and foliage.

Her breasts will give green milk when it is due.

Posgate Green milk!

Loftus Flora, I wonder why.

Cressey You wonder why what?

LofTus I wonder why you've never introduced us.

Would this place offend her? Would I offend her?

I am very hurt. Very.

Tell me, my onerous, secretive pedant,

How is the love progressing?

Does Flora crush you in her swan-white arms?

And smell of Roses at the Dawn of Time?

What of her cherry lips, and golden hips?

Is everything in place?

Perhaps you hide her from me, gentle Martin,

Because she's desperate to look upon.

Has she outrageous ears that at a wag

Can lift her clear of this unpleasant world, or

Are you a monster, Martin, all the time

Half mated to an equatorial bat?

Cressey Oh Georgie, don't, please don't!

For God's sake give a little.

Melt, thaw, erupt, do what you will;

Go mad, blaspheme, smash mirrors! Anything

To prove we live and breathe within a common

Envelope of air.

Something we had between us has collapsed,

And there is nothing but a draughty space

Dividing us where once there was a bridge.

Oh Georgie, where are you?

Loftus What's left of me is here. Don't try to move it.

One reaches a stage where keeping one's friends

Seems hardly worth the candle. 
As for making them - ha, that's grotesque!

I have become, if you like, self-sufficient.

If friends surround me they must not expect

A warmth I cannot feel. Why come at all, And argue round my body, I don't know.

I have never asked you to come.

But since you're here, remember,

I am all that is perfidious.

Remember this and it will give me peace.

Your manners and your customs and taboos

Meaning nothing to me. Your ideas of decency

Are part of some remote Arthurian legend.

What do you want?

Is it because you love to see a failure?

Is it because my failure must imply

Your small successes? . . . Success, that fearful thing

That binds you by a hundred icy wires

To the wrong pinnacle -

But failure sets one free.

Cressey Free! Do you call this freedom?

Lounging about like some degenerate sultan

On a rotting couch.

What sort of freedom does it give you,

This life of yours?

Loftus That of infinite choice.

It gives me everything:

From $\mathrm{A}$ to $\mathrm{Z}$ the bonfires of the brain.

Cressey Is that why you do nothing?

Because you are too full of images?

Is not this embarrassment of riches, This harvest of failures,

As bad as being 'prisoned in success'?

Loftus They are both dangerous....

That is why I lie here, as you say,

Like a degenerate sultan.

Cressey Have you no courage left? No Everest 
To scale in secrecy?

Loftus They climb high mountains to convince themselves

They are not frightened. They're afraid of fear,

But I - I am brave enough to admit my terror.

CRESSEY You have gone rotten.

Loftus I have gone rotten.

TiCKFORD And you don't care.

Loftus And I don't care.

TickFord How long is it since you last felt the urge

To wander in the sun? Or had the will

To stroll in a green field?

Loftus Once, long ago, it happened....

But by the time the ground floor hove in sight

The sun had gone behind a bloody cloud.

Tickford So the urge died for ever.

Loftus No. Recently I had it once again.

I felt a sudden spasm of energy,

So I lay down quickly, and the feeling passed.

Cressey I give up. I give up, absolutely and for ever.

Voices from below Come on down. Come - on - down!

Posgate Hark! How they giveth tongue.

Do I notice something smacking of impatience

In their flat chorus?

Cressey There's one more thing.

I have given up all effort to persuade you

To be human.

But what about your orphaned nephew?

Loftus Neville! What about him?

Cressey What about him! O my dear Georgie, He is your charge. It was for you to guide him Through these difficult years. You promised.

Loftus Why mention it?

Cressey He is downstairs.

Loftus No! At the party? No!

Tickford That strange, willowy boy?

$\mathrm{Oh}$, no. What is he doing there? 
Cressey What would he be doing,

But posturing and strutting like a bantam A pitiable thing.

You have all but ruined him by your neglect.

Did you know that Neville's miserable allowance

Is supplemented by unpleasant money?

Posgate Unpleasant money? What does that look like?

Loftus What do you mean?

Cressey There's nothing wrong in being rich,

Or a widow, or obese, or vain,

Or unctious, or oversexed.

Posgate I should say not.

Cressey But when these innocent ingredients

Are joined together in one heaving creature, It makes a vile and dangerous concoction.

Loftus Who is this gazelle?

Cressey There have been three of them since he left school, And none of them have been good enough for your nephew.

But Mrs Vole! You should see her!

Loftus I don't want to.

Posgate Not Anthea!

Is she downstairs? I can hardly wait!

Ah, Pringle, she would eat you up, she would;

Spectacles and all, if you took her fancy.

She'd have a time with you, I can tell you.

Pringle Why pick on me?

Posgate She'd change your theories for you

In half a minute, boy, with that dire smell -

Pine-apple chunks lashed home with ambergris.

Ah! Ha, ha, ha! Let's have her. What a globule!

Cressey It's a wonder they've left it so long

Before coming up.

Loftus No, I won't see them! Why should I see them?

Oh blasted hell, why did our mutual blood

Force this responsibility on me? 
Cressey You promised his mother.

TiCKFORD Oh my dear Loftus, what have you done?

Loftus I know, I know! But now?

No! No! Not now - some other time.

I'll help him - oh yes - I'll make a man of him.

But now - Oh, oh, oh-

Sudden loud knocking on the door and the shrill laughter of Neville as he dances into the room with the gurgling Mrs Anthea Vole.

Neville My, what a crush!

But, my dear, what a herd of men!

Oh, Uncle darling, there you are.

This is Anthea. Oh, Anthea darling,

This is Uncle Georgie. He's brilliant.

But brilliant! I told you about him.

My! (He gazes round the room in surprise.)

Mrs Vole Indeed, indeed - your uncle.

Are you ill, Mr Loftus?

Loftus heaves himself round to face the other way.

Really! How very strange! The things men get up to!

Loftus (suddenly sitting up) Neville, where are you, my boy?

Neville Oh, Uncle dear, you gave me quite a shock!

Do you smoke these?

They're just the teeny-weeniest bit scented,

But not a scrap of dope in them at all -

Oh, that would be too naughty, Anthea,

Wouldn't it love? Oh my!

Mrs Vole I would smack you.

Neville She would, you know! Wouldn't you?

Loftus (to Cressey) Convey this lady

To Posgate. I can see his pendulous tongue

Sluicing his shirt-front.

I want a word with my nephew.

Neville But Anthea has specially come to ...

Loftus Quiet!!!

Neville (starting nervously) Oh, Uncle darling, what a bore you are,

Shouting like that! You used to be so quaint - 
Such an amusing thing to have for an uncle, And so full of wisdom where I bathed my brow.

But, tell me, tell me - what do you think of her?

(Turns to look at Anthea.) Isn't she a poppet?

Loftus Your voice appals me. It goes on and on.

Change the shrill needle, child.

Neville If it wasn't that I hardly ever see you,

I'd swear that you were tired of me, Uncle.

Me, your little nephew.

Neville practises some new dance steps.

Loftus (aside) Is this my doing?

His slippery innocence is worse than vice.

What does he know of it all?

(Aloud) How old are you?

Your pouting mouth is still as wet as dew

From my poor sister's milk. ...

Stop jigging around!

Neville Oh how beastly of you.

You seem to think, because you're lying down,

You can be horrid. I can't help being vital. . . .

There was a time when you would lecture me.

My, it was lovely, unkie dear. I never

Listened, of course, but I adored your sermons.

They made me feel secure. But now it's changed.

Neville is on the point of tears.

And you never really want to see me, do you?

Why should you? Do you like my shirt?

Anthea thinks I dress beautifully.

Excuse me, Uncle Georgie.

After looking at Loftus pointedly, Cressey goes off with Neville, who moves away, and after staring blankly at Mrs Vole and Posgate, who are somewhat engrossed in one another, he moves towards the roofgarden to join Pringle and Tickford. Loftus avoids Cressey's eye, which has watched the distressing scene.

Mrs Vole The things you utter!

Anyone would think I was a young girl, 
When really I'm - well, you tell me.

What am I? Don't be too honest, you naughty man!

Posgate You are my temptress.

How do you balance such a bunch of bliss

On those sweet legs of yours?

Mrs Vole You're very wicked, but-

Posgate 'But'! I hang on to that 'but'.

Are you going to tell me that I attract you

The teeniest bit?

Mrs Vole You must wait and see, mustn't you, dear?

You mustn't spoil what might be a beautiful friendship.

I must find some nice girl for you, mustn't I?

Posgate Nice girl? What a ghastly thought!

Mrs Vole And for Mr Loftus, too. That's what he needs.

What a strange man. A genius, of course....

Some men seem to draw me to them, body and soul,

From the first moment. Now don't be angry,

You've got the body, Mr Posgate, but-

Posgate No soul? Is that it? Thank you very much....

The man's a failure.

Mrs Vole What does that matter? I love failures.

Successful men become so unattractive.

Tickford and Neville return from the roof-garden with Cressey.

Tickford No, no! It is the spirit that must guide us, not the brain

Which mutters, 'Leave this man alone.'

But at a deeper level my spirit knows

This is his Rubicon, and we must bear him

Down to his hostess.

Pringle What, bear him down bodily?

Posgate No, spiritually, in a frying pan.

Cressey He is my oldest friend, although he wounds me;

But I will risk the severing of this friendship,

For what you say is true.

For there are times you cannot leave a man

To stew in his own execrable juice.

He must be taken down. 
Hostess's lone voice Come - on - down.

Loftus is getting up on his elbow and at the same time drawing forth, from under his pillow, an old-fashioned pistol.

CREsSey What's that?

Loftus This, as you can see, is a pregnant sow

Fording a stream in Babylonian times,

On Thursday - at sunrise -

With love in its porcine heart, and a wasp

In its left ear.

CRESSEY Is it unloaded?

Loftus Not yet, but there's a litter on its way.

Neville Oh Uncle, I love you to the core,

But you won't be naughty, will you? Why d'you keep it Under your pillow?

Loftus Deliciously put together.

TickFord May I see it, Mr Loftus?

Loftus (after a pause) Of course. Let me make quite sure that it isn't loaded.

He puts the gun to his head and pulls the trigger. The hammer descends with a click.

Sometimes it works, and sometimes it doesn't.

Cressey This is horrible.

Voice of hostess Oh, why don't you come down? Oh, please come down.

Tickford This is too much. (To Pringle and Neville) Come over here.

The three move to one side.

Cressey Mrs Vole?

Mrs Vole Mr Cressey?

Cressey If Posgate can spare you for a moment, There's someone-

Loftus No, no.

Cressey who would like to have a word With you.

Mrs Vole Who would that be? Not Mr Loftus!

Cressey Mr Loftus. It was he, as you know, 
Who promised his own sister faithfully

That he would act as Neville's guardian.

Mrs Vole Sweet Neville. Where is he?

Cressey But you, Mrs Vole, have in your own way

Been such a mother to the feckless boy.

Who knows, it may turn out to his advantage

For his uncle to have jeopardised his future.

Mrs Vole (dreamily) Mm-mm-mm-mm.

Cressey Your influence upon young Neville, madam,

Must be overwhelming.

Enter Pringle from roof garden. He measures the width of the couch with his hands and compares it with the width of the doorway. He returns to roof garden.

Cressey Let me escort you to him, Mrs Vole.

Posgate Sly dog! Watch him closely, dear,

With those bright eyes of yours. Bah!

Mrs Vole Do you really want to see me, Mr Loftus?

Cressey Here she is, Georgie. Neville's foster mother.

What a lot in common you'll find to talk about together.

I'm sure you would rather be alone.

Cressey goes into roof garden.

Posgate The bloody fox. (Pours himself out a drink.)

Mrs Vole Oh Mr Loftus, how is it I find

That I have known you all my life? May I

Perch on this corner of your curious couch?

Now you must answer me, you naughty man.

You have been silent for quite long enough.

You must talk to me.

All from roof garden Posgate! Posgate!

Mrs Vole You strange, strange man. Why don't you talk to me?

Exit Posgate to roof garden.

TicKFord (without) It's quite against my dearest principles,

But, what else can we do?

Pringle (without) It will free him, I tell you.

It will free him, what! eh!

Excellent. 
Posgate (without) No, you can count me out.

Cressey (without) It is the only course.

Mrs Vole What are they all squabbling about, I wonder?

Not that it matters, dear.

Loftus There's something vile about you that attracts me.

You're old enough to be young Neville's mother -

What have you done to make him more than ever

The painted monkey?

Neville (without) Good gracious, but how dire!

My, my.

Enter Jane unobserved from roof garden.

Mrs Vole Why are you so mad with me?

Now let me straighten out this couch of yours,

And then we'll have a little talk together.

She starts straightening things about Loftus, which gesture of possessiveness is noted by Jane.

Mmm? Just the two of us. What we could do together!

Only think - do you like cruising?

JANE You're no good to him.

Mrs Vole Who is this child?

JANE I am Mr Loftus's friend.

Be careful of her, Georgie,

She is wicked.

Loftus That's the only thing I like about her.

Mrs Vole Really!

Loftus (to Jane) How appropriate that you should see me now.

A disgrace to my gender.

Let me be a warning to you.

JANE I will never leave you.

Loftus What a terrible threat, my dear.

Don't say such things.

My freedom is the only thing I have.

I must be left alone in every sense.

Go! Go, now, both of you. Give me air.

There is suddenly a great commotion from the roof garden as all return into the room through the french windows, while the two 
ladies move to one side.

Posgate What a hope! Ha, ha, ha!

Neville But, my, how dire!

TICKFORD Mr Loftus, you must trust us.

You are too ill to know what's best for you.

We must take it upon ourselves in the name of love.

CRESSEY Truly, Georgie, you will thank us for it.

God knows I hate to be a party to it,

Or any kind of violence.

JANE (moving protectively to Loftus) No!

Loftus What are you trying to say?

Posgate Ha, ha, ha!

Cressey We have no choice. Come along, Pringle.

All except for the two ladies and Posgate begin to close in on Loftus.

Pringle Fascinating.

JANE Let him alone!

TiCKFORD We are taking you to her party, as you are

In all humility and unadorned.

Oh, this will cleanse you in the eyes of Heaven.

Posgate They don't know you, Georgie.

The four begin to raise the couch.

Jane How dare you!

Neville Oh Uncle!

Mrs Vole What is it all about? My dear, it's extraordinary!

Voice of hostess Come on down, oh can't you?

They begin to move the couch but are stopped in their tracks by the vehemence of Loftus's attack.

LOFTUS Ignorant fools!

D'you think that you can change me

By shouldering my body down the stairs!

Lower me down!

Lower me, I say (They lower)

Before your watery blood is on my hands.

Stand back - ah, look at you!

To think you had the nerve to stricture me.

What do you know of me? 
Posgate What did I tell you!

LofTus Of all of you there's one I loathe the most:

(pointing, after a pause, at Posgate)

That smirking pug.

Posgate (with a surprised yell of indignation) Hell's bottom!

That you could turn upon your only friend!

I tried to stop them, Georgie! Damn it all.

What gratitude!

Loftus Who would you have to sponge upon, friend Posgate,

If I were to shake off this heaviness

And find some kind of pleasure in the world?

Tickford True, true.

Cressey Well spoken, Georgie.

Loftus (to Cressey) Be quiet.

Why don't you swill your own sweet stable out?

Tickford I can't stand by while you-

Loftus Then sit down.

Voice of Hostess I hate them! I hate them!

Loftus Poor thing. The cause of it all.

Go down to her. Get out of here -

I am no longer 'at home' to the world.

I have discovered something:

You are all as weak as I am. Ha, ha!

Pull up that rug, sweet Jane. A cigarette.

Give me that book. (Turning over a few pages)

'With a host of curious fancies

Whereof I am commander,

With a burning spear

And a horse of air

To the wilderness I wander.' 3

Neville Oh Unkie, my own Unkie!

Loftus 'With a burning spear

And a horse of air

To the wilderness I wander' (The bell rings.)

'Wilderness' - what is it in that word that shakes the heart 
Clean out of bed?

What is your wilderness? I have my own.

It has no boundaries, but shifts its grey

And crumbling landscapes through my skull, Shuffles them, while I stand, and stirs the dark

Air that I breathe. (Enter a woman undiscovered.)

Oh, you innocents! You nonentities, Caught up in the illusion that to move Your bodies to and fro is to be alive.

How have you added to the sum of things?

The brooding images

That haunt my fatuous hours have sharper focus

Than anything you see with daylight lenses.

If you could see what I see, you would find

The world too vivid, too extraordinary,

To be endured. It is not easy

To blind the brain, and pull the curtains down

Across the vision. No. It is not easy

To ignore the stories that are being told

Moment by moment by a torn sleeve,

By a tilt of the hat, or the humped shoulder,

Of the delicate suffering at one's elbow.

Oh God! The endless, generous profligacy

Of every sliding second. There's no end

The invention is so rapid, various, profluent. ${ }^{4}$

Another and another, each one in the weird wake

Of something vaster.

Fingers are tapping at an ice-cold railing.

A heel as long as a new pencil slithers.

A million hats are at their favourite angles.

A million fags are spinning, drooping

Or bristling from lips like threads, like wet fruit,

Or like rifts in cold plaster.

Clay miracles float by and tears are flowing.

The eyes like constellations swarm through London.

There is no end of it. 
I have enough to last me all my life.

The fleeting face of some dark motorist

Can haunt a man for ever.

Oh you are lucky -

That you see nothing but the things you see.

How can you understand? You've never been

For breathless journeys through wild literature,

Or cut cold steps to a white altitude

Of crested logic;

Or toiled alone when labour was like sunrise,

Raddling the limbs, or like a furnace

Burning behind the brow.

You have not worked - you do not know the word:

Work that brings forth;

Draws out the sweat, explodes in steel or music;

Work that eats up the hours and makes a man

Into a man again. (Pause)

Neville (awed) Did you say 'work'? I do not understand.

What has happened to you, Uncle Georgie?

You have always said that - oh Uncle,

Do you mean it? Do you?

Because I would join you, Uncle, I would help you

All I could! Oh my - oh my - !

LofTus (in a whisper) Forget it. I was carried away.

Something I thought was dead began to move.

It was nothing. Goodbye, ladies and gentlemen.

(He begins to sag) Make it - goodbye -

Cressey But, my dear Georgie, I-

Loftus Don't talk to me. Do something more for me -

Something I need desperately.

JANE I will do anything for you.

What do you need?

Loftus This room to myself.

If you have, between you all, a grain of compassion, Then go away.

Shamefacedly, they begin to file out of the room. 
TickFord I have done what I-

Loftus Go.

Mrs Vole Really it has all been very-

Loftus Go.

Pringle We will see. We will-

Loftus Go.

Posgate Steady on, old sport, steady-

Loftus Go.

JANE (in a whisper) Go, go, go.

She follows the others out.

Cressey Oh, Georgie, I-

Loftus Go...

On the way out Cressey suddenly notices the newcomer, concealed on one side.

Cressey Flora! What are you doing here?

You must come with me.

Flora, holding the lapels of his coats, gently pushes him backwards to the door.

Flora (mimicking Loftus) Go!

Loftus now sees Flora and they look at one another spellbound. They know that from this moment their lives are threaded together. Yet, in spite of, or because of, this pulsing nearness, they cannot think of anything to say. They look about, almost wildly, in the suppression of their mutual excitement, for something - anything - that will give them the chance to talk to one another. At last, in exquisite desperation, Flora turns to leave the room.

Loftus, his eyes roving desperately about the room, lights on the cuckoo clock.

Loftus But look and see! It's a cuckoo clock.

Flora It is indeed. No doubt of it. It is. Is it?

LofTus It is. But it won't work ...

Flora Too many cooks? Perhaps it's out of broth.

Loftus Out of this world, and out of everything, Time, luck and temper.

FlORA No wonder it won't work. What can be done?

LOFTUs Each time I push it back into the clock, 
It tumbles out again.

FLorA That is wrong. It ought to know its place.

There was a cuckoo once that tried to make

A summer, but it died of overwork.

Loftus Wasn't it a swallow?

Flora No, a cuckoo.

Loftus It was a swallow!

FLORA Who cares? It was a bird.

Pause

Loftus Shall I show you ... what I mean?

Flora Butplease.

With Flora watching awed, and aware that some great metamorphosis is taking place, Loftus gets out of the couch, puts on his slippers, rises, proceeds slowly to the clock.

The cuckoo is too high to reach from the floor, so he stands on the chair Pilcher previously used for the same purpose and, balancing precariously, restores the cuckoo. Again it does not come out. Loftus is about to descend when the seat of the chair gives, and his foot goes through it.

Loftus Ha, ha, ha! Ha, ha, ha, ha, ha!

Flora Ha, ha, ha!

Loftus My foot went through the seat.

FLORA I saw it do it!

Loftus Ha ha!

FLORA Ha ha!. . I know a good man for chairs.

He weaves the canes, you know, in and out.

Loftus But this one hasn't got any canes.

Flora Then he won't be any use, will he?

Loftus None at all, I imagine. ... What's his name?

FlorA Baker.

Loftus That's a pleasant name, isn't it? Pleasant and simple.

Flora Very pleasant.... and so simple.

Loftus And is he nice?

FLORA Frightfully nice.

Loftus How nice.

Another long silence. 
Won't you sit down?

Flora Thank you, Mr Loftus.

Loftus You are wearing yellow. Would you call it yellow?

FLorA I would certainly call it yellow. Oh yes. Quite yellow.

Loftus Yellow ... for what?

FLORA Yellow for fun ... yellow for yellow's sake.

Loftus Yellow for Jason's Fleece.

Flora Yellow for gorse and daffodils.

Loftus Yellow for bile ... I said yellow for bile.

Flora I heard you.

Loftus And yellow for the Whang Ho.

FlorA Why?

Loftus It means the Yellow River. It is very long;

And makes its way through China.

Flora How dogged!

Loftus Would you like to see it? There's a globe somewhere.

FLORA Immensely.

Loftus pulls an old globe across the stage.

Loftus Here's China.

FlORA So it is.

Loftus You're looking at Africa.

FLORA I was born in Africa.

Loftus To the rhythm of the Congo drums?

Flora No, to the annoyance of Dr Baxter.

Loftus Who was he?

FLORA My father. Let's change countries.

Loftus Where are you now?

Flora England.

Loftus London.

FLORA North of the river.

Loftus In a studio flat.

FLORA With an old couch.

Loftus And a globe. (Turns from her)

And a game of make believe.

FLORA Make believe?

Loftus Yes, 'make believe'. Revolting as the sight 
Of adolescence wallowing in the moonbeams.

Flora You are too serious.

Loftus Me serious! Ha, ha, ha!

Flora And uncertain.

Loftus Uncertain!

FLORA I heard you talk of work as though it were A sunrise to be swallowed.

Your words rang out like bells - but not for long.

Loftus What of it?

My graph jerks like the Alps, and I have found

It is the crests that wear the dunce's caps.

It is the burning crests that are so cold . . .

Oh damn all this. What do you want with me?

Flora I have always wanted to meet you,

With or without your dunce's cap.

What is the matter' Are you unhappy?

Why do you stare at me?

Loftus If I had met you twenty years ago . . .

Flora When I was three?

Loftus No, no! When I was twenty. The world Spread out before me with its dazzling toys. I had no qualms. If I had met you then . . .

Flora What would have happened?

Loftus I would have been all wind and high romance, My ears a-tremble and my teeth on fire! A sprig of youth! A dog! A stag! A peacock! I would have trailed a hundred miles of ink Across a hundred pages; my damp letters, Bursting the pillar box, would have turned The postman dizzy with the smell of roses ... If I were twenty now! . . Thank God I'm not! My age has saved you from a screed of poems; From all the little nods and smirks of love; From secret rendez-vous and all the slobber. You have been spared a lot.

FLorA I certainly have, haven't I? 
Loftus There was a time when I could crumple hearts

Like eggshells in my hand - but worse than this:

I fell in love with love and could have climbed

Inordinate trees by moonlight,

And from the black and silver of their crowns

Obtained a glimpse through some curtain chink,

Of half your ankle.

Flora Hardly worth it. I do see that.

Loftus You mock me.

FLorA Of course I mock you. When a man is childish,

What else is there but to tell him so?

Or am I very wrong and very rude?

I do hope not - but, oh, why harp on age?

And what you might have done when you were this

Or that - in such and such a place, if only

Your grandma had been less fond of skating.

That leads nowhere. You are here and now.

As for your age, it's nothing but the biggest

Bore of a subject. ...

What is more serious is your bout of spleen,

Your boastfulness, your efforts

To shock me, and the way you throw up words

Like a smokescreen.

You are too real for this hide and seek.

To real - not too old ...

Are you afraid?

Loftus I am afraid of magic,

I have no longer the desire

To cope with it. I do not want to see,

Touch, or hear it. The responsibility

Of a vision is too much. To the vandals with it!

You see in me, sweet child,

The original traitor.

FLORA Is that what I see in you?

Perhaps - that among other things.

It is the other things that loom so large. 
Loftus 'Loom' is the word.

I never asked to see you,

I never asked to see your perfect face,

I never asked to see the way you walk;

It is unfair to break into my life

Without so much as knocking at the door.

What is your name?

FLORA Flora.

Loftus No! Not Martin's ... .?

I thought you were ... .?

Flora Yes, I know.

Loftus How odd. (Pause)

Good luck to him.

FLORA I'm afraid not.

She goes to the window and looks out. It is dark now.

There lies dear London and the world beyond,

Africa, China ... and the Whang Ho river ...

Yellow as what?

Loftus Yellow as cowardice.

Flora And a hunter's moon ...

O Mr Loftus - shall we go out together?

Loftus Great God! Why shouldn't we?

(Looking at his slippered feet) Like this?

Flora Why not?

Loftus Why not! Why not! Away!

He spins the globe and makes way for Flora who goes out first.

As Loftus disappears, the Valet enters. He scowls at the door through which they have vanished. Then he approaches the globe, muttering as he proceeds. Suddenly he brings his hands down upon the globe, stifling its rotation.

Pilcher Oh, no, you don't! 
INTERVAL 


\section{Act II \\ Scene 1}

A week later. A bright morning.

The curtain rises to the hum of a vacuum cleaner. It is still Loftus's apartment but transformed and is now neat and bright as a new pin. Pilcher is wielding the vacuum and there is one other figure in the room - Neville. This young man, who has recently moved into his uncle's flat, is apparently no less industrious than Pilcher, for he is making notes in an impressive-looking tome. At first it seems they are absorbed in their tasks, but it can soon be observed that neither of them is really so. They each seem to be waiting for the other to relax, but each time Neville looks up, Pilcher is hard at work, and vice versa.

The phone rings.

Pilcher Which one of 'em would that be?

Neville Oh dear, do you think it's Uncle?

Pilcher No, no. What would he ring for?

Neville But he might, mightn't he?

Pilcher is about to lift the receiver, but turns at the last moment.

Pilcher You really think it might be?

He switches on the vacuum and holds the receiver to it for a moment, then switches off. But it is not Loftus. It is Mrs Vole, Neville's exparamour. While Pilcher speaks to her, Neville reacts by making wild signs and dancing about the floor in agitation of body and spirit. He has been forbidden to speak to her.

Pilcher Who? Oh yes... Mrs Vole... What can I do for you, Mrs Vole? .. What's that, Mrs Vole? Mr Loftus? He has gone 
to the bank ... yes, the bank! . . . Yes, Master Neville is here ... (greater agitation from Neville) ... hold the line, please ... Oh yes, Mrs Vole ... yes, indeed ... I will fetch him ... that's it . . that's . . . it. (He leaves the receiver hanging. To Neville) What's the matter?

Neville 'What's the matter?' Oh golly! Oh flip! Why must she ring me? I won't - I can't. Tell her to go away. Uncle said positively I mustn't ever see her. Switch her off - she's bad for me. Uncle said so. (Mrs Vole's voice starts croaking.) I promised him faithfully - oh, listen to her - tell her I've changed my life! Tell her I'm too young. I'm only a boy, really. And she's too fat anyway - oh golly, d'you think she heard me! ... Oh Mr Pilcher, where are you? ... What are you doing? . . . Look at her, hanging there by the neck. . . . I'm queasy ... I'm sickening . . . I feel queer ... Where are you, Mr Pilcher? Cut her off . . . I can't . . . can't . . . Uncle told me not to ...

He has gradually crept up to the receiver.

Pilcher Master Neville, you can't ...

Neville Oh, go away!

PILCHER (complying with reluctance, snatches up the vacuum cleaner) Only too glad, I can tell you. (Exit)

Neville Anthea ... What do you want, Anthea?... Yes, I feel lonely ... Yes, I know ... Are you cross? ... Yes, I know ... Did you say I was naughty? ... Oh my . . . yes, of course I love you, but Uncle, he's my sort of hero - and so kind . . . yes, Uncle . . What? Oh . . no, he's not here - he's at the bank, you know, and all dressed up ...

Half way through this conversation, Posgate, as in Act I scene I, has slouched through the door. He has taken stock of the situation, already picked up the only cigar left in the box and poured out the last drink. Posgate reaches over and takes the receiver by the cord but Neville, aghast at seeing Posgate, who is also on Loftus's blacklist, snatches the receiver back and blocks it with his hand.

You! Uncle said you weren't to come here. You're bad for me too. Everybody, almost, is bad for me! 
Posgate Ah, Neville, to think that you could desert your Uncle so. To think that you could leave him in the lurch. Your Uncle! My best friend - the giant among dwarfs.

Neville But Uncle said-

Posgate Uncle is not well. We must take care of Uncle, mustn't we? Together we could save him. Couldn't we? Now listen. (He winks and takes the phone. Neville marches to his books; pretends to read.) How is my Anthea? My peppermint cream. No. It's Porky. Now listen. I have a favour to ask you. It's for my oldest friend, Georgie Loftus. He's in trouble - he needs money desperately. Listen, darling. Why should he borrow it from a bank at a high rate of interest while we, his friends, can lend it to him at a lower. After all, Anthea darling, what on earth are we on Earth for but to help each other. Lend a hand, you know, and trim the boat. We want to help him, don't we?

Impressed by Posgate's 'altruism', Neville has crept up, and is standing behind Posgate.

Neville (impulsively) We do ... we do!

Posgate Anthea, dear... now listen, Neville is here with me ... he is signalling to me ... what is it, Neville, old chap? ... Aha ... yes ... a good idea! (But Neville is just standing mutely) 'Scuse me, Anthea, Neville says why don't you come around at once ... You can? Right away? ... O love bird, we can't wait for you. Bye bye. (Posgate rings off.)

Neville I never said that!

Posgate No, but that's what you wanted to say, eh, old son?

That's what your better side wanted to say.

As Posgate lifts his glass to drink, Pilcher enters.

Pilcher Go easy with those smokes, sir.

Who d'you think will take the can back

When he find 'em dwindling?

Posgate Quite right, quite right indeed. Why, what a place You've made of it. All we need now is the money

To keep it up ... I hate it, Neville, boy, It's like a bloody clinic. But enough, 
We have work to do.

Pilcher and Neville (together) Work!

Posgate 'Work that brings forth; draws out the sweat,

Explodes in steel or music ...

Work that eats up the hours and makes a man

Into a man again.'

Neville But oh! But Mr Posgate!

That's what Uncle said, the other day!

And you remembered!

Pilcher Pah!

Posgate Yes. Yes, indeed. Your Uncle is a great man,

Truly great . . . but ... (Neville does not notice the point-

ed 'but', so Posgate repeats it loudly) . . . BuT!

Neville But what?

Posgate You say 'But what?' Ha! I can tell you what!

I have picked up a thing or two, my lad,

Since I first took up shaving.

I've met a pack of all sorts in my time,

For I'm an easy fellow - not so dumb

As many like to think....

So listen to me, Neville, there's a boy!

Great men, for all their greatness, have their own

Achilles elbow.

Neville Heel.

Posgate What's that?

Neville Achilles heel.

Posgate Quite right, Achilles heel. There's not a man

Without it. There are bishops scared of cats,

And kings who snore like pigs. Some hide their ancestry,

Some have poor judgment when it comes to women,

And we privileged, privileged to know

One of the great, and we must save him from

His own proud self - for he is blind, my boy -

Blind to the wiles of women. Oh Neville, Neville,

Where is the Georgie we used to know?

Georgie the genius with his flutes and crayons, 
His Latin and his wisdom and his dreams

That left us gaping? What a hideous thing

To think of him in chains. Oh God, that lion,

That golden lion, lying down in chains.

Neville You've never talked like this to me before, sir.

No - nor looked so honest.

Posgate Don't call me 'sir' - I'm not as old as that!

My name is Porky. We are men together,

Though you're too young to have observed the sharp

Edge of a brain soften and become

Like dough on a bread board.

If he should slither into matrimony,

And buy a bowler hat and go to work,

And dandle children on his pinstriped knees

Like any other ass, then I have done

With friendship. Listen, Neville - are you with me?

We love him, don't we, in our different ways?

Neville Flora has always been so sweet to me,

Oh my ...

Posgate Sweet to you! If I didn't know you, Neville,

I'd say that you were selfish.

What has our pleasure got to do with it?

It's not ourselves we are thinking about -

It's something bigger than our bloody selves -

Oh, stone the crows! It's Georgie or it's nothing.

Neville I know, I know he shouldn't marry her -

Or anyone else - oh flip, it's awful when he loves her so.

Posgate Love doesn't last. It's like a coloured toy

That, overwound, busts up - the mainspring snapped;

The colours fade, and then it's chucked away.

Love!

Neville I hate it too ... I hate that Mrs Vole -

She nearly stifled me - Oh my, and me so young.

It wasn't funny.

Posgate Forget her. Are you with me, or have I

To fight for him alone? 
Neville I'm with you, Mr Posgate, - but I'm frightened.

The bell rings. Enter Jane and Victor Green, a mild little man in bowler and glasses.

JANE Why must this place be always full of faces?

Where is he?

Posgate I expect he's looking for you.

JANE (ironically) Ha, ha, ha!

Posgate What have you brought with you?

Jane A man.

Posgate Or a mouse.

(To Victor) What have you come for?

JANE What have you come for? What have we all come for? We have come like vultures out of the sky - we have come to the place of the kill. We all want something of him. And he wants nothing from us.... This is Victor. Victor loves me. Laugh if you find that funny. Victor doesn't find it funny. Nor do I. I feel sick. (She sinks down onto the couch.)

Posgate Stop moping and get her something.

Neville Poor Jane.

Neville pours out a glass of water for her. They crowd around the couch.

Posgate (to Victor) Don't you ever utter some kind of little noise?

Neville How d'you feel, Jane?

JANE Vile, thanks. Where is he?

Posgate We don't know where he is nor who he's with If anyone.

JANE If ...

Neville Uncle's at the bank. Pilcher told me so.

Posgate The bank. Ha, ha! How will that help him?

What he needs is something more than the bank can give him.

He needs his friends, his old friends, his true friends.

He may not want us, but by God he needs us.

It isn't only cash, it's - O damn and blast it! 
It's brotherhood! Or nothing.

Neville Oh Mr Posgate, sir! - Oh Porky!

Posgate You are a part of his existence, Neville -

But look at you, more generous than us all,

Yet pushed aside.

And Jane, my sweet, you are his guiding light -

If he but knew it. As for me, d'you think

I'd ever dare to lift my head again

If I forsook my only bosom friend?

God knows he's far beyond me, but I'd rather

Walk in his shadow than - (seeing Victor)

Oh Lord, are you still here?

The bell rings and Posgate hustles Victor to the door with him. He returns without the little man but with Mrs Vole.

Mrs Vole My dears, the room's been sterilized. Some woman

Has been at work. Well, well - oh, Neville, darling,

Why have you been so naughty? You have almost

Broken my heart - oh Porky,

Another of your dreadful neckties, darling.

Where's Mr Loftus? (Seeing Jane) Oh my dear,

What is the matter?

Posgate Jane isn't very spry - and nor are we,

For George is in trouble. Money trouble,

Up to the neck and down. O Lord above-

If only we could help him.

JanE Help him? It isn't simple. If it was,

I could deliver him - from everything.

Mrs Vole How sad.

Posgate Oh, it is cruel when great men decay

For lack of dough.

(To Neville) What are you staring at?

Neville It's Uncle's green book.

Mrs Vole What about it, dear boy?

Neville Oh Anthea, he's been looking for it for ages.

Oh my. He'll be so pleased.

Posgate What's in it? Chunks of Latin? 
Or drawings, or what? Let me see.

He tries to take it.

Neville No, no - it's Uncle's secret.

Jane Put it away.

Neville (turning the pages in spite of himself) Oh my! It's lovely.

You wouldn't understand, Anthea.

(Absorbed) Sssh ... Listen.

'I am too rich already, for my eyes

Mint gold: while my heart cries

"O cease!"

Is there no rest from riches, and no peace

For me again?

For gold is pain

And the edged coins can smart

And beauty's metal weighs upon my heart.'

- Oh my...

Enter Loftus, unobserved.

Mrs Vole It rhymes.

Posgate Go on, I get it.

Neville 'How can I spend this coinage, when it floods

So ceaselessly between the lids,

And gluts my vaults with bright

Shillings of sharp delight,

Whose every penny

Is coloured money?'

Posgate Go on.

Neville 'Storm, harvest, flood, snow,

Over the generous country as I go

And gather, helplessly,

New wealth from all I see

In every spendthrift thing,

Oh then I long to spring

Through the charged air, a wastrel with not one

Farthing to weigh me down,

But hollow feet to crown,

To prance, and laugh! My heart and throat, and eyes 
Emptied of all

Their golden gall. ${ }^{5}$

Posgate Bloody marvellous. What I understand of it.

Mrs Vole So restful.

Neville Shut up!

Mrs Vole Neville!

Neville Oh Anthea! (He sees Loftus approaching)

Oh Uncle, I've been reading your book ...

Loftus holds out his hand and takes it.

LofTus It had a meaning once.

He slings the book across the room.

Posgate Georgie!

Loftus Where have we met before?

Wait, it's coming back ... you are that thing

Forever on my shoulders - Posgate -

What are you doing here? ...

Why don't you go and breathe a different air,

In some alternative universe? (Looking at Jane)

A phase has come and gone. Across the skyline

Another kind of dawn is on the brink

Of breaking. Oh my dears! My dear dears!

Why don't you all join hands and go away

For ever and for ever?

Neville Oh Unkie, I can't stand it. What is it

We've done to make you sound so dark and cold

Just when we want to help you?

Loftus Help me?

How do you think you can do that?

I am supremely happy,

Happy as a bluebottle.

Now there's a fact I know,

And yet another

Pilcher enters

And another

Pilcher exits

Jane, Jane. Surely you know above all 
How I am only happy when I'm miserable

And miserable when I'm happy?

You wouldn't interfere, I know, my love

With such a perfect balance.

JANE Do as you wish. Be as you wish,

It's all one.

Have we been dismissed?

Mrs Vole I don't know what's happening.

LofTus (turning to her) My soul is happening,

What's left of it.

(To Posgate) Just go, dear chap, just go.

Your friends will follow.

Posgate stares unbelievingly at his 'old friend'.

Neville (running up to Loftus) How dare you hurt a human being so!

I'm not afraid of you, Uncle.

You are cruel! Cruel!

$\mathrm{Mr}$ Posgate loves you. He worships you,

He remembers your poems and the things you say.

Do you think we are against you?

Do you think that is why we are all here?

No! It is because we love you, and because you are blind.

Oh Uncle ...

He's even brought Anthea here to help you,

Because we know you have no money left.

Loftus What?

Neville Anthea longs to help you,

So do we all.

Loftus Help me! Help me! Help me!

Oh pretty Neville -

You are all love and weakness, you are young,

Have you never heard of hypocrisy?

Posgate Hypocrisy! ... Ha, ha!

Coming from you that's very funny, George!

You, who have taught me everything I know,

And made me what I am - me and my friends ... 
Just look at Neville - he is of your making -

Poor little devil ...

Neville I feel all right. It is Unkie who is ill,

And needs to be looked after.

Mrs Vole Are you refusing to allow me to make

Your life a teeny bit easier?

It won't be much . . .

Loftus Why not? (Pause)

I'll think about it.

Posgate You will, Georgie. You will?

Loftus Who knows?

Neville And you will let us help you? And

You won't be horrid to Mr Posgate?

He is so helpless, like a poor animal.

(To Posgate) I never used to like you, but . . .

Posgate Thanks for nothing.

Georgie, can I get you a drink?

Loftus Do, do.

But don't smile. Please don't smile -

It makes me uneasy.

Posgate Oh cockatoos to that, old lad.

He sees Flora upstage, out of the view of the audience.

Flora May I join you?

JANE What have you come for? The body?

Flora How did you know? How are you, Georgie?

You look unhappy, Mr Posgate - almost as though

You had a secret sorrow,

And as for you, Neville, oh dear,

Are you never going to smile again?

Never - no more?

Loftus Where have you been? What have you been doing?

Flora Flat hunting.

Neville Oh, but Jane has said that Uncle can stay here, here!

Flora No - but how very kind, I am so pleased.

JANE Why?

FLorA Because I've had no luck. I have no flair for flats. 
What a relief!

Neville Not only that, but Anthea has been so kind!

Flora I'm sure she has. What has she done this time?

Neville She is ... she is ...

Mrs Vole Dear boy, it's nothing.

FLORA But what is it?

I'm longing to hear.

Mrs Vole Well dear, if you must know -

I hope to lend dear Georgie what he needs

To tide him over. And it's such fun to give.

Loftus Everyone loves me.

Flora How can we help it? We do nothing else.

We buzz like wasps around a jam jar ...

What have you been doing?

Loftus Doing? I've been abroad

Tasting the luxury of isolation.

I've wandered through the park as though it were

My own green island.

FLORA You wandered through the park!

Not on the grass, I hope?

Not on the grass where little insects thrive

Amongst the tangled fibres.

Oh no! You could not do it when

Everyone has been so kind to you,

Giving you this, giving you that,

Fawning upon you ...

Oh no, you could not walk upon the grass

And crush the little creatures.

If you go on like this the time may come

When you will find yourself strong as a tiger,

Free as an eagle - and oh Georgie, dear,

What would the insects think?

(Pause)

Now I must go. You have been very kind

To let me stay so long.

I trust you will continue with your meeting. 
Goodbye to you all. (Going)

Loftus Don't go.

Flora Why not?

Loftus Because I love you ...

Against all the crystals and that constellation

That hangs about my head; against the burning

Omen that has warned me since I met you, Against the tugging of my watery ribs

That cannot come to good - against all these

I love you - against wisdom and the warning

Of the murmuring marrow, I adore the way

You place your little feet, or raise the slender

Arc of your eyebrow.

During this proclamation Jane has left, to be followed, one by one, by the others. The two are now alone.

The atmosphere, fraught with the probability of a love scene, changes and becomes factual and nervous. Loftus, finding he is alone with her, begins to pace the room.

LofTus (cont.) There is no future. Wipe away my words

They were perhaps too real to be true,

And all I want is to be far away -

With money in my pockets. My own money,

Not Mrs Vole's - but my own -

To last me 'til I find some kind of work

... a carpenter's would do. ...

I'm fond of wood.

Flora So you have jibbed at Anthea's offer?

That smacks of honesty. Oh Georgie, dear,

It smacks of honesty ... (pause)

I have the money for you.

Loftus You have!. . I would never have ...

FLORA I know you wouldn't.

Loftus I don't understand you. If it is dishonest

To borrow from that woman, why is it honest

To sponge on you?

FLORA You were not taking honestly from her. 
But with me it is different.

You see, I have one condition.

(Pause)

Loftus What is your condition?

FLORA I have already told you.

If you can give your word then I will take it Just as if you should stretch your hand to me,

Then I would clasp it.

If you could find within yourself the white

Light of pure trust, oh, then the two of us

Could sail above suspicion. In that way

Be honest with me, Georgie.

Loftus Honest! Honest!

What does honest mean?

I am so desperately in need of money,

How could I trust myself? . . .

To hell with your fine phrases ... I adore you.

FLORA You have the truth of it although you try

Your best to hide yourself away from it,

My darling.

Loftus holds her and stares into her eyes, then draws her to him, but the kiss is broken off by Flora who moves slowly and with serene thoughtfulness to where her bag is lying on the table. She withdraws her cheque book, writes a cheque, tears it out, and holds it out for Loftus to take. He is dazed and does not look at it.

Loftus What is it?

Flora A bit of paper.

Loftus I don't want it.

Flora Then you are no true lover.

For all your protestations

You are nothing but that conditioned bore,

The decent chap.

You, with your imagination,

A decent chap!

Stop being decent - it's too easy.

Be alive, be real - love is not a game 
Of obvious reflexes and old school ties.

Let us be true or nothing.

Holding up the cheque with one hand, she caresses his cheek with the other.

I want proof, darling,

Proof that you have Gehenna in your blood,

Not Norbury.

Loftus (grasping the hand at his face) Put it on the table.

FLORA No.

Loftus Is this the only way to prove

I love you - to accept this donation?

How very squalid.

FLORA It is a golden squalor. All our future.

So take it as a symbol of our love.

Our dangerous love.

Their hands join upon the cheque and together they put it down upon the table.

Now you are twice the man.

They embrace again. The bell rings.

Loftus You have vanquished me.

Ring

Flora I've such a lot of it, darling.

Loftus What, money?

Flora Yes, darling, so much.

Loftus Ha, ha, ha, ha!

FLora Ha, ha, ha, ha!

They laugh together. Ring.

Loftus There is a kind of ringing in my head.

FLora Me too, a sort of interrupted buzz.

Loftus Ah, mine is different -

It is continuous

As the sound of a beehive

In the dawn of the honey-coloured world.

Buzz-zz.

Flora Buzz-buzz.

And mine is interrupted as the heart 
Is interrupted in its secret tapping,

At the first shock of ... of . . . this.

LOFTus This?

FLora All this,

All that has led to this,

All that this leads to.

All that is this,

All that this is.

They kiss. Ring.

Flora Who was he, d'you think?

That little man?

Loftus Was it me, my humming bird,

Reformed in the distorting mirror

Of your adorable brain?

Flora Oh no, for once it wasn't you at all.

It was an altogether different kind

of creature.

A funny little man,

Standing outside the door.

They are still spellbound as Victor appears out of the shadows clutching a note in one hand and his bowler in the other.

Loftus What funny little man?

What kind of funny?

Loftus sees Victor.

Flora A worried little man with a bowler.

Loftus And holding a piece of paper?

Flora He wasn't holding a piece of paper.

Loftus Well, he is now.

Flora sees him. Victor edges a little nearer, holding the note awkwardly forward. He is embarrassed but determined.

Victor Excuse me ... I didn't know ... I rang the bell ... several times.

Flora Can I help you?

Victor Help me? No... no ...

I don't think so. (Turning to Loftus)

You are different from what I imagined. 
I have a note for you ...

That is, if you are Mr Loftus. (Pause)

Are you Mr Loftus?

Loftus Irrevocably.

Victor I have a note for you from Miss Nicholson.

She says-

Flora Miss Nicholson? But won't you sit down?

Victor No, thank you ... no.

He stares out of the window.

FLORA Were you her-are you her...?

VICTOR No, not at all, I am-

Here is the note.

Miss Nicholson says to wait for a reply.

Loftus (talking across to Flora, quizzically) Miss Nicholson says to wait for a reply.

Flora And you are - ?

VICTOR I am nothing. I am -

My name is Victor Green.

Loftus Victor Green! So you are Victor Green.

Flora We have heard of you so often, Mr Green.

VICTOR I suppose so.

FLORA You look so very sad.

VICTOR Do I? It doesn't matter.

I can see I never stood a chance.

I can see what she means now.

And how I must have bored her.

I'm very ordinary, really.

But still . .. mustn't grumble.

Flora Oh my poor, dear man.

VICTOR (to Loftus) I did not mean to talk - but seeing you

I bear no grudge.

But it is horrible to know Jane bores you,

You see, she's ...

Please take this note - that's what I came for.

Loftus How you depress me.

VICTOR Do I? It doesn't matter. 
You've got what you want - that's all right -

There's no hard feelings.

Nothing makes any difference anyway.

Flora How well I know that feeling, Mr Green.

Victor You? Oh no.

FLORA Why not? But please sit down.

VICTOR (sitting down abstractedly and speaking to Loftus)

I wasn't going to tell you anything,

But you looked so happy, it is hard to swallow.

Ever since that day Jane first met you

She has been cold ... cold.

But still . . . mustn't grumble.

Loftus You make my heart bleed.

Why should I be accountable? What right

Has fate to make a torturer of me?

(To Flora) Am I responsible?

Because of me his Adam's apple bobs

Like a cork on the swell;

Because of me his hands are fidgeting.

Forgive me, Mr Green, that I should ever

Have allowed my mother to have borne me,

It was absent-minded of me.

Flora Don't tease him, darling.

Loftus Tease him? Oh no...

I want to save him. I will save him.

Victor must snap his fingers in love's face.

Flora Love is inside him, Georgie.

How can he snap his fingers at his heart?

I know it all; the darkness and the light,

For you have taught me pain as well as joy.

Like Victor I'm in love and try to keep

Afloat on Love's weird waters,

For Love is weird, and those who drown in it

Return, in another state,

Like those who have seen ghosts or unicorns,

Or heard fierce bells strike out in empty cities. 
(To Victor) You are possessed and nobody can help you.

Return to her and tell her once again,

For what you have to give is marvellous.

Loftus shrugs his shoulders.

You know it, darling -

Don't shrug your silly shoulders.

VICTOR Please, will you take the note.

I didn't want to bring it anyhow.

Flora (to Loftus) Stop looking desperate.

Take the note from him. He is feeling ill.

Loftus takes the note mechanically.

LofTus (to Flora) Then why protract this business with your theme

Of love? That gets him nowhere.

Love isn't everything.

(To Victor) Now listen to me:

There is no doom in this;

Stand up and square your shoulders, clench your teeth, And tread your softness under!

Flora Softness?

Loftus And laugh, boy, laugh!

Ha, ha, ha, ha, ha, ha, ha!

Flora Oh, anyone can see with half an eye

He's in the throes of it and helpless.

Loftus (to Victor) Helpless? Do you admit it?

VICTOR If I am helpless, it's my own affair.

Flora Of course it is. And helplessness is nothing

To be ashamed of. It is hopelessness

That is belittling.

Loftus It has belittled me,

My pretty dazzler. Oh indeed it has.

(To Victor) You see before you, Victor Green, a man

Who, once upon a time, lived his own life

In his own way, disturbing nobody -

Save those who came too close, as children do,

Who dare each other, for the thrill of it,

To touch a sleeping $\operatorname{dog}$... 
Yes, here I lay, on this moth-eaten couch,

Content to be a kind of golden sluggard,

Refusing to be drawn into the whirlpool

Of a world gone mad.

Here on this couch I took my brain for walks,

Or brooded on lost volumes, where green islands

Burst from the pages, exploding palm on palm -

For reverie is stronger than a bomb.

What happened to that man who walked the streets?

Who stared through lighted windows ...

And found in every face its own particular

Heaven or Hell? What happened to him?

He has lost his courage and can only

Focus on one thing - one little thing,

To the exclusion of a whirling world -

One little thing - (to Flora) your face.

Flora How awful for him.

Loftus (to Victor) Be careful, Victor, not to lose your soul,

For everyone must try and save the little

Ghost that is not for sale.

Your ghost of glory, your horse of air!

When I stood up and tried to be what some

Might call a man, my virtue ebbed away,

And it was nothing but a replica,

And did what others do.

Flora And what was that?

Loftus I fell in love, I fell a thousand feet

Because of love and cracked my teeming head

Upon a rock, and all my brains poured out

In one great sheet of opalescent oil.

(To Victor) Now that's a thing you must avoid, you

know.

It kills the little ghost behind the breastbone,

That is more delicate than any woman.

Love is a common thing, and much the same

The whole world over, but the little ghost 
So easily betrayed, is never quite

The same in anyone.

Victor Excuse me, Mr Loftus, I think I . . .

Loftus Don't get excited, boy. Take my advice:

Pack up your bag, and off to sea with you.

And sling your bowler to the bloody winds!

Loftus shies Victor's hat across the room.

To hell with Jane and all the other Janes

That clutter up the globe.

Flora I never knew you could be so cheap.

Loftus Or you so dear,

All air and radiance...

But you will age - you will age.

Flora Be cruel if it helps you. Bare your teeth, And snarl like other dogs. Destroy yourself, And lick your lips to see how rapidly

What's good in life can turn into decay.

Oh Georgie, Georgie ...

It isn't long ago we were so happy . . .

Now there's no finding you.

LofTus Flora -

FLorA Back to your couch,

Back to your dreams,

Back to where you came from.

Oh my darling,

Get out of my life!

Loftus (dazed) No . . . no . . .

VICTOR Mr Loftus?

Loftus What...

VICTOR I've been thinking about what you've been saying.

Loftus (abstractedly) Why?

VICTOR About trying to be strong - and -

Loftus Life is too much for me. It battens on me.

I am no kind of man for love or friendship.

I am a beggar, boy, who cannot bear

To pick the pennies from my wooden plate. 
Whatever's given me I have to pay for

In some quite different way.

VICTOR You're crumpling up the note from -

Loftus Now go away.

VICTOR I thought perhaps I could help you.

Loftus has wandered to the table. He picks up Flora's cheque and looks at it for the first time.

LOFTus This piece of paper could propel me round

The world five times in liners white and gold,

But there'd be no escape from this damned carcass.

I'd have to go with me.

He tears the cheque up, crumples it in with the note from Jane and throws them both away.

(To Victor) Tell them there is no answer ...

Go, go, go.

VICTOR (at door) I'm sorry for you.

Loftus Go.

He heaves a long, shuddering sigh and begins to wander erratically about the room. On the way he picks up his green book, glances at a page, throws it into the couch, but follows it and reads another bit; throws it away again, follows it again, this time to dust it and put it on his desk.

There he sees after a few glazed moments that he is looking at one of Flora's slender, long black gloves. He picks it up, gradually, as though he were handling something delicate and of great price. He opens his left hand and places it on his palm to see the difference in size, then suddenly flings it into his big wastepaper basket. He strides about the room, going so far as to fling open the door of the roof garden. Everyday noises from the street.

While he stares across the rooftops Pilcher comes in and looks around without seeing Loftus. He is about to return when Loftus comes striding in and on passing the basket sees the glove. Then, as though to banish it from his mind, he begins feverishly to cram the basket with newspapers and an armful of loose papers from his desk, the green book along with the rest.

Filling it to the brim he flings himself onto the couch, but almost 
immediately he is on his feet again, on his knees by the waste basket. While he is rummaging frantically, the loose papers fly out in all directions. Now and then he pants her name.

At last he finds the glove, smoothes it out, gets to his feet. He stares at the glove, flings it down and runs through the door. He feet can be heard getting fainter and fainter as he pounds down the stairs.

Pilcher, amazed, stares about the stage and then sits down, shaking his head, as though this were the final proof of his mater's madness.

\section{Curtain}





\section{Act II \\ Scene 2}

A month later. Sundown.

The stage is empty. Disorder has returned to Loftus's room. The bucket, basin, etc. are as before. In addition, the upstage pane of glass of the French windows opening onto the roof garden is shattered. Across Loftus's couch, with the usual assembly of things collected about, is his scarlet dressing gown; for a brief moment when the curtain rises it might be taken for the man himself.

During the dialogue that follows between Pilcher and Cressey, the latter behind the former, entering from Pilcher's quarters, Loftus's servant is 'busy'. He is at the grate trying to strike a match, the last in the box. He fails and is forced to enquire whether Cressey can give him one. Cressey hasn't any. Pilcher is forced to light the match from the geyser off stage, and hurries across the stage before it burns out. He succeeds in lighting the log fire, but burns his fingers in the process. He then puts Loftus's slippers before the fire. A thoughtful gesture, but easily done, as indeed all his touches are. 'Most effect for least effort' appears to be his motto.

Cressey (entering) What's that you say?

Pilcher I'm saying as how time is running off. I'm busy, sir, and can't afford no lingering.

Cressey What about Neville?

Pilcher Questions! Questions! Questions!

Well, what about him, eh?

Why, he's been sacked as well -

He's sacked the lot of us ... including her. 
But I can't stand here gossiping all day,

My master will be home before you know it.

Ugh! What a farce! My master working!

It isn't right. . . .

I must lay the tea and disappear, I must,

Before he puts that face of his around

The flaming door. Believe me, Mr Cressey,

Now's your time to go.

Cressey Why? What are you frightened of?

PIlcher Frightened? Why jibe at me, sir?

I'm only telling you how Mr Loftus

Don't want to see nobody.

He wants to be alone with peace around him.

That's why he's sacked us all.

As he says this he goes to where a pair of Loftus's trousers are hanging and takes out all the money from a pocket.

Cressey What on earth are you doing?

You're sacked but you remain to brew the tea,

And fish for change in Mr Loftus's pockets ...

Explain yourself.

PILcher (counting change) There's shopping to be done.

Provisions must be paid for, mustn't they.

Cressey (mystified) But you've been sacked, haven't you?

Pilcher He must eat all the same, mustn't he.

Agreed?

Cressey But heavens alive, man, this is laughable.

Why don't you go and find another job?

PILCher Another job? What, after all these years?

You must be joking, sir! Besides ... ah, look,

I can't stand talking here . . . besides . . .

Cressey Besides what? Speak up!

PILCher I will not answer if you're rough with me.

Cressey Well?

PIlcher He's going mad. He must be.

Cressey How?

Pilcher Oh, ain't it more than obvious indeed? 
Who in his senses would do such a thing

As sack a faithful servant?. . .

Now look at this (pointing to broken window): 'e slung 'is flute at me.

'E said I was an ugly fox, 'e said.

Now that's not nice, nor is it truthful neither.

But I must nurture 'im - and dodge 'im too, Like hide 'n' bloody seek, because he's crazy, And it's all her fault.

Cressey What do you mean? Who?

Pilcher Miss Baxter. Who else?

Cressey We'll leave her out of it, shall we?

Pilcher As you please....

We were so happy, me and Mr Loftus;

A year ago there was such quietness.

$\mathrm{Oh}, \mathrm{Mr}$ Cressey, sir, you can remember

How I would pander him.

'E used to chant long Latin hymns 'n' study

Dust through his microscope.

This was our house, it was, before she made

A madhouse of it.

Cressey It has returned to what it always was, A shambles vile and disgraceful. Why don't you do something about it, Since you refuse to leave?

PIlcher Haven't I told you twenty thousand times That I've been sacked. You don't understand, I have my pride.

Pause

Cressey Pride. Good pride and rotten pride, And the wounded sort that fills the head with blood So that the ears sing, and an agony heat Pricks at the skin. ... . What happened? I must know what happened.

Pilcher I don't know what the quarrel was about. I'm no eavesdropper, sir. 
Cressey No?

Pilcher No! And I wasn't here. All I can say,

There was a quarrel and he banished her.

Cressey Banished her?

PIlcher Sent her away. 'N' little Neville too.

The same day, later on, when he got back

From tramping London.

He wasn't doing no harm, was Neville ...

Sitting on the couch, swinging his legs,

As innocent as a flower. Mr Loftus

Don't half work sudden when it comes to it.

He sent them both away.

' $\mathrm{N}$ ' he didn't chase her neither like the last time.

Cressey How do you know all this and yet know nothing?

You are not square with me.

What did you overhear?

PIlcher Nothing. ... I sensed it all. You may not know

How sensitive I am.

CRESSEY (pointedly) Now think again: I'll make it worth you while.

What kind of quarrel was it

That they've made no attempt for thirteen days

To see each other?

What did they say, man? What was it about?

A noise at the door.

What's that?

Pilcher (afraid) I told you not to dawdle!

Pilcher pretends to be polishing a chair as Loftus comes in. Loftus does not notice him and Pilcher sidles along the wall to the doorway through which he disappears. A long pause.

Cressey Hello. (No answer.)

I said, 'hello'!

Loftus The buzzards watch me from a hollow sky.

Cressey What's that?

Loftus How brave of you to come so close to me,

A soul contaminated. Look, my illness

Drips from my fingertips like some foul dew 
From clammy fungi. Ah, but I am touched

That you should wish to witness my decayNoise of a party gathering in the same flat below.

You and your selfless friends.

Cressey Georgie!

Loftus Why do you haunt me?

Why am I singled out to be the quarry?

Why am I hounded?

A burst of laughter and music from a radiogram as Loftus speaks. He goes to the open roof garden window and shuts it to cut off the sounds.

D'you hear that noise? It is the pack at play.

They only need a little liquor now

To fetch them up like beetles on the march

To steal it from me,

Irrevocably to steal and murder it.

Cressey Steal what?

Loftus All that is left of silence-sacred silence

That last cool tarn - the virtue at my centre.

You and the rest of you!

$\mathrm{O}$ ignorant of what it is to be

Made of particular clay.

Cressey 'Particular clay'? What's that?

Loftus It is a daemon sleeping in my guts;

It is a white dawn trembling in the marrow;

It is a sense of height; it is the scorn

Of kings. Where are my slippers? ... Ah.

It is that thing, perhaps, that draws

You and your friends, as though I were a magnet,

So that my soul must choke and gasp for air,

So close you press upon me.

You have brought failure to me,

Failure that smells like death -

Sweet, horrible and musty -

Failure that I must carry with me

Like a corpse in my arms, 
Heavy as all dead things are.

And the face of the corpse is mine.

That is what you have done to me...

I hear the rattle of a dry wing,

I hear the sound of water and of fire,

I see all kind of things. Great mandrils lurching

Through poisonous waters with all their manes alight.

I see ... I see ... what do I see?

Why, Mister Cressey, my one-time crony.

If only your name was Tony,

Why then I'd greet you as 'my crony, Tony'

Or 'Tony, my crony' - or macaroni.

So much more amusing than 'Martin'.

Cressey I'm in no mood for this....

You know why I've come.

Loftus Do I?

Cressey Of course you do.

Loftus Then you must remind me.

Cressey Remind you! Remind you of Flora?

You go too far for safety. ... Where is she?

Loftus She is walking about on the earth,

Her high heels tap the crust of it.

Knock, knock - who goes there?

A creature that is plumage to the eyesight

But to the touch is metal.

Cressey That is a lie; she was all wit and candour.

Sweet as a hazel nut; there was no metal.

Loftus Did you not hear her tinkling like a glass?

Yes, there was more of glass in her than metal.

Cressey O God, where is she?

You have deserted her.

Loftus I have deserted nothing but an empire

Of love, and like all empires, love can crumble.

The women of the world inhabit her,

And there's no gesture she can make but stems

From centuries of guile. 
Flora indeed ... she is not worthy of you.

Cressey What! Not worthy of me! Are you mad?

What do you mean?

Loftus Not-worthy-of-you.

Cressey Be careful,

Your temper's not the only one on record

To run amuck. Worthy of me: great God!

You make me sick. ... What is all this?

Have you abandoned her?

Loftus She abandoned me.

Cressey You?

Loftus Though I intrigued her for a while -

Like a new toy.

Cressey I don't believe you.

LofTus Blockhead!

Did Flora never say she loved you once?

Pause.

Cressey It was long ago.

LofTus (taking him by the shoulder) Listen, old friend.

She was beautiful as ever came our way.

She was intelligent. She was wealthy.

But being a woman, she had no option

But to destroy us.

(He has picked up his same old pistol and loads it.)

We are well rid of her. She flattered us

And fanned our vanity,

And all but coaxed us into Lethe's water,

As sirens coax poor sailors down the tide.

(Referring to his pistol:)

It never worked; not properly.

Presumably it did dire business once.

Cressey I'm not interested in your pistol. Damn it all,

Why must your brain hop off at every angle?

Have you no news of her?

Loftus I'd like to get it working smooth as butter.

Cressey Why? Why? Why? 
Loftus Because I have a love of things that work.

I sometimes feel I'd like to work myself.

Cressey You!

Loftus Me. Yes, me. If I worked perfectly,

Or even half as well as that old clock,

I would be famous. Lord, I have the visions

But never seem to have the right-shaped bottle

To pour them into.

Offers cigarette. Cressey shakes his head irritably. Loftus chants the following:

Loftus 'At the

Lo-cal

Cemetery

They've been

Wery, wery busy wiv

A bran' new grave, 'cos

Snoozer, he snuffed it.' ${ }^{6}$

Have you ever thought of suicide?

Cressey Have you gone mad?

Loftus Mad? Did you say 'mad'?

I have gone sane. That's much more difficult.

My brain is as clear as glass and I can see

The quiet on the other side of chaos ...

The unending quiet.

Cressey Unending nonsense! I can see it now.

You drove her from you with your sickening ego!

She did not leave you - she was driven out... .

I sometimes wish he'd done the same with me

And done it twenty years ago; before

I knew how treacherous this friend could be

Who filled my boyhood as a painter fills

His canvas to the brink.

D'you think that I am worried by your gun

That's pointing the wrong way for suicide?

Yes, you are mad. Your madness frightened her.

Yes, mad and futile too! 
Loftus Futile?

Cressey Futile for all your overweening pride.

Your nephew thinks so too; your servant thinks so;

And Posgate; yes, and Jane.

As for sweet Flora ...

Loftus Then I am mad. I must be, for the sages

Have said that this is so.

My intellect is diseased; my upper storey

Is full of rats. Observe the Bedlamite

And Prince of Monomania,

As he approaches on his cloven feet...

Now tell me, Martin, why are you so sure

I will not pull the trigger?

That is the kind of thing that madmen do.

Cressey You dare not and cannot.

It does not work. To brandish it like that

Is nothing but the gesture of a schoolboy;

You are slipping, Georgie.

I have no longer any feeling for you -

Despicable failure.

Loftus, not listening, raises the pistol and aims at the globe. He pulls the trigger and the pistol explodes - setting the globe whirling on its axis.

At the sound of the gunshot the muffled noise from below stops and there is dead silence. This is broken after a few moments by shouts from below and the sound of feet on the stairs. Loftus goes onto the roof garden, shutting the windows after him. He is lost in the darkness without. Cressey moves downstage and is almost hidden in the shadows.

Neville (entering, sees Loftus's scarlet dressing gown on the couch and stops dead) Unkie! Unkie! Are you all right?

Posgate (entering) Where's he? Where's Georgie?

(Staring into downstage shadow) Who's that?

Cressey? What the hell are you lurking there for?

Where is he?

No reply. Enter Pringle and Tickford, and Mrs Vole last. 
Pringle Where is the body? Well, well, well. It's all very - oh, it's only you, Cressey! Where's Loftus, my friend, and what was that sharp noise? Tell me all!

He goes to the french windows and opening them looks out without seeing Loftus. Neville has gone to search within and returns from Pilcher's quarters.

Neville Where is he, Mr Cressey? Oh my goodness, where is he?

Tickford (to Cressey) Are you not feeling well? Where is our friend? Was there a pistol shot?

Neville Why don't you answer? We thought that Uncle might have killed himself.

Mrs Vole Or that you'd killed him. Aren't I a silly one?

Cressey Have none of you, to let your soul out, slammed A single door? Yes, slammed it shut for ever? Was that, perhaps, the noise that brought you all Tearing up here, agog - your tails on fire As though you'd rather see his body, dead, Than mine, alive.

Mrs Vole What a quaint expression! 'Tails on fire'.

Posgate What's the matter with you?... You look -

You look more like a ghost or something than a man.

Loftus's face appears at the window.

Tell us the trouble.

Neville Oh, Mr Cressey, do. He was so good

And kind to me; I want to see his face.

Where can he be? And where can Flora be?

She was so-

Posgate Sh - Quiet, laddie - That's a smarting point.

Now listen, Cressey, it's the same as ever:

We want to help him to his feet again.

Pringle and Tickford are together upstage, right of the roof garden window. Posgate, Mrs Vole and Neville are sitting on Loftus's dressing gown on the couch. Cressey's line of addressal from downstage left is directed to Loftus's face at the french window.

PRINGle He has always interested me profoundly.

I said, when I first saw him, 'There's a man 
To fill a thesis with.'

TiCKFord You look at it differently, Mr Pringle.

I am not interested in your approach;

As though Mr Loftus were a guinea-pig.

The man has a soul. Perhaps a vaster soul

Than we with all our pettiness, theories, and smugness;

$\mathrm{Oh}$, he is on a scale that thrills and daunts us.

Pringle Come, come - it is a case of -

TiCKFORD It is not a case at all.

It is a living battle. His proud heart

Wars with his brain and only God can help him.

God, through our mediation. Throw away

Your textbooks and your case sheets and your files!

Throw them away!

Neville What can we do?

Posgate Leave him alone! There's been enough of nagging.

I could look after him.

Neville You! No, no! He's had enough of you!

Oh my, what am I saying?

Mrs Vole What a rude boy.

Neville Shut up!. . .

Oh dear...

(To Cressey) You've known him for so long;

Oh ever so long; he told me himself.

You were children together, weren't you, sir -

You and Unkie?

You are the one to tell us what to do.

Posgate You slammed the door? It sounded like a pistol.

But where is Georgie?

Cressey I'm looking for him myself. I've been looking for years.

Posgate Where is he?

Cressey I'll tell you where he is.

He is here (pointing to various objects of Loftus's possession).

He is here

And he is here. 
And again he is here.

He is everywhere.

Here a bit. There a bit. My life is littered with him. (Directly at Loftus) I met him first when I was twelve years old. We were new boys together. We seemed to take to each other, though we were very different. From the very first he was popular with everyone. He was what we all wanted to be: the laziest boy in the whole school, but always at the top of the class. He seemed to know everything before it was told him, and was never to be found listening to the master. And I, working like a slave, was just below him. Why I struggled so hard I don't know. . . .

At last, one term, I found myself ahead. He had been more indolent than ever and I more determined than ever to prove myself his equal. . . . It was a friendly rivalry in which he took no part. For the first time he came second. For the first time I was ahead. What was my reward? The jeers of the boys. It was Georgie who had won again. It was I who suffered.

It has always been the same. He has always taken what I wanted most - plucked the bright mantle from my shoulders, and tossed it, when the time came, in the mud. And yet, he was my friend.

When we left school, it was always Georgie they spoke of. It was always Georgie who was going to set the Thames on fire. But his sloth, like a disease, began to spread and he turned traitor to his gifts. Even his poems became unintelligible. No one could understand a word of them. He didn't seem to care. And then, six months ago, I fell in love. Knowing his genius, I hid her from him. His genius for disruption and decay. But she discovered him at last and the rest you know. I will not bore you with it. . . He plucked a rose and tore its petals off.

Neville You are right! You're right! You must be! Oh my ... He gave me this gold tie-pin. Now what will happen? 
Cressey Nothing. That is the tragedy.

Nothing will happen. He will go on rotting

And as he rots the company he keeps

Will rot alongside like a soft flotilla

Of slimy planks in his black shadow.

The time will come when beggars, thieves and gamblers

Sit where you're sitting, while this one-time man

Gobbles up degradation like a lizard

Gobbles up flies.

The kiss of death is on him.

There's nothing left to say.

Pause

TickFord There's all the world to say! What right have you

To stand in judgment on a man so rare,

So bleak, so proud, so wayward, but so full

Of his own essence that we pale before him.

Posgate finds flute and plays softly. Loftus's face disappears.

No man has any right to judge the moment

For God to bring the final curtain down,

Nor any right to think that all is lost -

When God may intervene.

Pringle Really!

TickFord Oh let us pray for him.

Pray that the forces that are locked in him

May be set free.

Pray for our God to intercede for us,

And give him health again - $\mathrm{O}$ pity us

For our small souls.

Posgate (stopping his play on the flute) Look here-

TickFord We only see one side of this great structure

That is our friend - the side that crumbles daily,

But it may be the other side of him

Is golden granite; strong as love itself.

I will not be a party to your fears.

God will protect him.

Silence 
Mrs Vole I don't see any point in staying here,

Can't we go down again?

She rises, goes to the door, at which she waits for Neville, who remains seated, staring.

Cressey (loudly to Loftus offstage) What else is there to do?

Pause. The others, except Neville, stare at the blank window at which

Cressey is looking. They see nothing.

Or to be said? . . . Nothing.

They all move to go out and converge in a mass in the doorway. Only Neville remains seated on the couch.

Neville (to himself at first) There's something most unfair . . .

Poor Uncle hasn't had a chance at all

To defend himself.

(To the others) I hate you all!

Mrs Vole Oh, pull yourself together, Neville, dear!

Neville I don't know what I'm thinking any more.

He moves to join them and just as they turn a wave of music fills the stage: Loftus has opened the french windows. He enters, apparently oblivious of the others. He shuts the window after him to cut out the sound.

Loftus Look at this fly that keeps on coming back

To settle on my shoulder. Look at its wings

And the scissor motion of its sizzling thighs.

Compared to such a miracle as this

Our bright inventions are of small account -

Our degradation nothing. Watch it! Watch it!

There ... there ... forgive me, Fly,

That we are underdressed and hideous

While at your breast an emerald momently

Flames into copper light.

Ominous murmurings of crowd in street far below; the sound of a distant fire bell.

Ah, she's away again: look! There she goes;

Come, Neville child, and we will trace together

The air-route of her choice.

Away again? Oh what a bird for circling. 
I wish I had your independence now. ... .

(To others) My only life has reached the half-way mark

And I am wingless but am full of all

That genius eats.

What I can do there's no one else can do

Unless I do it!

What I can think there's no one else can think

Unless I think it!

Oh God, to be this insect whose existence

Fulfils itself.

I have the power and I have the globe

Hot in my hand.

There's nothing that can stop me once I take

The burning high-road.

I must not sleep.

Sweet life can never sleep ... and never tire,

A comet falling down the winter sky,

A wrinkle forming gently, year by year

Across (pause) some forehead and the life of dreams.

He has been following the fly around the room and he now swipes at it with a folded up newspaper and kills it.

Fire bell louder.

Ha, ha, ha, ha!

Do you understand?

He throws open the window and shouts come up from below.

See how the great gates open at my touch

And here before me spreads a realm of gold.

Enter Pilcher suddenly followed by a plume of smoke. He is coughing and cannot get his breath. He disappears into his own quarters, having mouthed the word 'Fire' and pointed to the ground. The bell of the fire engine, which has been increasing in volume, now stops, having reached the site of the fire. A dark cloud of smoke swirls past the window. Cressey leaves at once. Posgate and Tickford rush to the window. The roar of the crowd is now heard together with the hiss of hoses, and the radiogram still blaring away. Pringle has at the same time run onto the roof garden. 
MRS Vole (bolting off at an incredible speed for a woman of her size) Help! Help!

Neither Loftus nor Neville has moved. Loftus is looking about the room in a sort of growing ecstasy. Neville stares at the reflection of the flames on the opposite building. A record on the radiogram comes to an end.

Neville Look at those lights! Oh my!

O Unkie, dear! What is it?

Posgate (to Loftus) Stop grinning like a bloody maniac, boy!

A fresh disc on the radiogram starts.

Let's get out of here.

Pringle (reappearing) No time to be lost!

Downstairs with us all! Downstairs with us all!

Exit Pringle.

Neville (at window) Oh my!

Tickford Come along, you! The stairs!

He takes Neville out with him. Posgate follows. Re-enter valet from his quarters loaded to the teeth with an astonishing assortment of personal junk.

Pilcher Fire! Mr Loftus, sir!

We're on fire!

Loftus, bursting with excitement, seizes Pilcher.

Loftus Who cried 'Fire'? God bless him!

Who cried 'Fire'?

Pilcher What? Well, I . . .

Loftus You are Voice. Someone has switched the light on

Inside my skull. Where is that book of mine?

My green book, Pilcher - where the devil is it?

PILCHER What a time to shout for a book!

Leave me alone....

Exit

LOFTUs (searching helter-skelter for his book) The gods are with us this is the beginning!

Eat up, eat up, fire!

Eat up the filth of the last forty years!

Posgate returns. The fire is now much brighter and the noise of crack- 
ling louder.

Posgate Come, boy, come - there's a dear fellow.

He catches hold of Loftus's arm. Loftus is standing by the table with the phone which at this moment begins to ring.

Loftus Leave us, Posgate! This is a private call

From Paradise.

I will follow you down - as I've always done.

Posgate Do you promise?

Loftus I promise you.

Exit Posgate. The phone is still ringing but before Loftus can pick it up it cuts off, together with the music of the radiogram, a female voice crooning a love song. This scene is held for a few seconds, then all the lights in the room go out, leaving only the illumination of the fire reflected off the opposite buildings.

And a pillar of fire by night...

O cauterize the earth, you lovely flames.

This is primordial stuff.

A voice without, giving directions. Then a beam of light shines through the window. It is from a fireman's helmet.

Fireman (giving directions into his phone) How many of you there?

Show yourselves.

How many?

Loftus One. - O fireman, how thy brass doth twinkle!

Fireman (entering through the window) Can you manage? What?

Any invalids? What are you waiting for?

Loftus Hold on a minute, fireman.

He suddenly remembers where his green book is, fetches it, and joins the fireman at the window.

Farewell to all that stinks,

All that corrodes;

To all sheet anchors,

Handcuffs and muzzles.

Farewell to the flesh,

Farewell to memory - for I have no wish to remember

The least iota of what I was.

The future, like a pomegranate, sits 
Upon my plate.

Ha, ha, ha! Oh, I am happy, fireman! I am happy!

Fireman (climbing onto ladder) Give over now! Lord, strike a light!

Loftus There is no need, sweet fireman. You are blasé.

This may be nothing to your jaded eyes -

It's quite a fire to me!

He is about to stride the window sill when the fireman's communicator buzzes. The reflection of the flames begins to dim. The fireman signs to Loftus to wait and listens to the crackling voice.

Fireman (into phone) Right - yes - yes - alright.

Loftus All things are dirty but the splendid flame.

What's keeping us?

Fireman No need to worry, sir. We've drowned it.

Loftus Down the golden ladder. What's keeping us?

Fireman Hold your horses, sir. Don't get excited.

We've drowned it, I say ...

You're quite safe up here, now ...

Silence. The fireman switches off his headlight. The stage gets darker.

No need to be disturbed.

Silence. Then a faint patter of rain.

Loftus It is raining. (He shuts the window.)

Fireman (tapping glass) You're a lucky one!

Silence, save for the faint patter of rain. The room is now completely dark.

(Into communicator) Charlie!

(A croaking reply.)

Lower!

He sinks out of sight. A few moments, darkness then the lights blaze on again. Loftus looks around the room. He finds he is still holding the green book. He starts to read it; moves automatically to the couch where he lies down and draws his dressing gown over him. He finds a pen in the pocket of this garment and leans back meditating, the pen at his lips. By and by he begins to write.

Enter Pilcher cautiously. He notices Loftus in his old position and feels reassured. He is followed by the porter who has helped to carry up some of the paraphernalia Pilcher took down. 
PILCHER What a shocking turn-out!

Fire, rain and hosepipes - the perishing lot!

I'm fair drenched, my friend.

Porter Me too. What's more, my blooming bed's afloat

Down in the basement. (He looks around the room)

It ain't a lark, I tell you.

But look at you ... you ain't suffered nothing.

Pilcher Aye, it's suffrin' what does it, friend.

He takes the porter's hand, warmly.

Come again, some other time,

When you're shipshape, Arthur.

PORTER That's it.

Pilcher Good night to you.

Porter And you.

Pilcher Cigar? (offering one from his 'private' collection.)

Porter (selecting one) That's it.

Pilcher God bless.

The porter leaves and exits with the unlighted cigar in his mouth. Pilcher goes to the door and bolts it.

Pilcher (approaching Loftus, who is still writing) Would a cup of tea be nice, sir?

No answer - Pilcher bends to see what Loftus is writing.

There is no ink in the pen, sir.

No answer - Pilcher pats his master affectionately on the shoulder.

There, there -

We'll have you back, sir, like you always was.

Good friends must take care of one another.

The valet switches off the lights, and for a few moments before he draws the curtains the walls are fantastically lit by patterns of moving neon signs. After he draws the curtains he retires to his quarters in the darkness. The swish of the rain increases. Suddenly, the phone rings, the doorbell goes, knocking, voices without and below. But one by one these disturbances cease and silence returns. Very softly the cuckoo calls. Only the monotonous downpour can be heard, exactly as at the beginning, and as the drip, drip of the leak into the bucket begins, the CURTAIN comes slowly down. 
THE END 


\section{Notes}

I The quotation is not from Horace, of course. They are the opening lines of Shelley's 'Arethusa' ( 1820 ), in which the mountains are 'Acroceraunian'. In the typescript referred to in the Introduction as item 4, 'Acoreraniam' has been revised (in ink, the only amendment thus) to 'Acoseranian'.

2 A puzzling piece of Latin: Ab imo pectore ('from the depths of my heart') is attributed to Julius Caesar, and $a b$ initio means 'from the very beginning'. Both SP and item 4, however, have $a d$ for $a b$ (i.e. 'to', instead of 'from') in both instances. This would translate roughly as 'to the depths of my heart and to the inner beginning.' I have opted for ' $a b$ ', presuming that ' $a d$ ' is a typo.

3 This is from the last stanza of Tom o'Bedlam's celebrated song, which dates from the early seventeenth century.

4 The preceding lines closely resemble a passage in Peake's 'London Fantasy'.

5 The poem is almost word for word Peake's own 'Coloured Money' (I937).

6 This is the refrain of a popular music hall song, 'More Work for the Undertaker' which originated in the late nineteenth century and enjoyed a revival in the interwar years. 